\title{
Extracellular Vesicles in the Pathogenesis of Viral Infections in Humans
}

\author{
Allen Caobi, Madhavan Nair and Andrea D. Raymond * (D) \\ Department of Immunology and Nanomedicine, Herbert Wertheim College of Medicine at Florida International \\ University, Miami, FL 33199, USA; acaob001@fiu.edu (A.C.); nairm@fiu.edu (M.N.) \\ * Correspondence: adraymon@fiu.edu
}

Received: 27 July 2020; Accepted: 20 September 2020; Published: 21 October 2020

\begin{abstract}
Most cells can release extracellular vesicles (EVs), membrane vesicles containing various proteins, nucleic acids, enzymes, and signaling molecules. The exchange of EVs between cells facilitates intercellular communication, amplification of cellular responses, immune response modulation, and perhaps alterations in viral pathogenicity. EVs serve a dual role in inhibiting or enhancing viral infection and pathogenesis. This review examines the current literature on EVs to explore the complex role of EVs in the enhancement, inhibition, and potential use as a nanotherapeutic against clinically relevant viruses, focusing on neurotropic viruses: Zika virus (ZIKV) and human immunodeficiency virus (HIV). Overall, this review's scope will elaborate on EV-based mechanisms, which impact viral pathogenicity, facilitate viral spread, and modulate antiviral immune responses.
\end{abstract}

Keywords: exosomes; extracellular vesicles (EVs); viruses; pathology; HIV; ZIKA; retrovirus; herpes virus; coronavirus; therapeutics

\section{Extracellular Vesicle (EV) Biogenesis}

EVs formation occurs in most nucleated cells and is evolutionarily conserved [1]. Bodily fluids, including saliva, CSF, blood, and urine, all contain EVs. Initially, scientists thought EVs were waste products, but researchers have found that EVs are integral to intercellular communication and signal transduction [2]. EVs are classified as one of the following: apoptotic bodies, microvesicles, or exosomes (Figure 1). Cells undergoing apoptosis release apoptotic bodies 1-5 $\mu \mathrm{m}$ in diameter and are also capable of releasing smaller EVs such as apoptotic microvesicles $(<1 \mu \mathrm{m})$ [3]. However, it remains unclear if the formation of apoptotic microvesicles occurs under the same mechanisms responsible for microvesicle generation in healthy cells [3]. Unlike apoptotic bodies, microvesicles and exosomes are derived from healthy cells, have been extensively characterized, and are critical in regulating the immune response and intercellular communication [3]. Microvesicles are primarily generated via shedding/budding from the plasma membrane (PM) and are between $150 \mathrm{~nm}$ and $1 \mu \mathrm{m}$ in diameter [4]. Microvesicles can also transport pro-inflammatory miRNAs and cytokines such as IL-1 $\beta$, thereby initiating the acute inflammatory response and modulating the immune response [4,5]. Unlike microvesicles, exosomes are intraluminal vesicles (ILVs) ranging from 30 to $120 \mathrm{~nm}$ in diameter, are formed during the maturation of multivesicular bodies within the late-endosome via inward budding of the endosomal membrane, and are released into extracellular space when a multivesicular body (MVB) fuses with the PM [1,6,7]. However, the ILVs may undergo degradation if the MVB fuses with a lysosome instead of the PM. The process determining the fate of MVB fusion, in which the MVB either fuses with the PM releasing exosomes or fuses with the lysosome for lysosomal degradation, is not yet fully understood. However, it is hypothesized that MVB fate results from inhibition of either pathway as lysosome inhibition results in increased EV release [8]. 
A

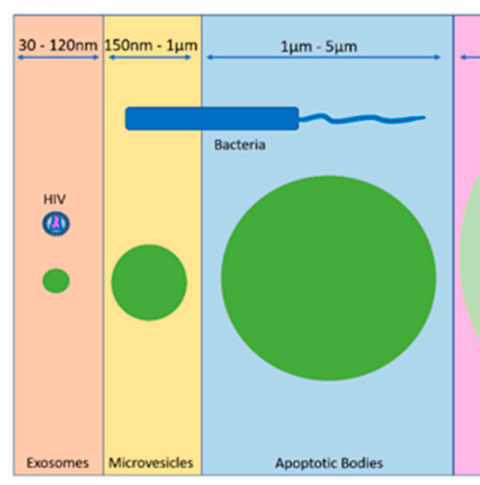

B

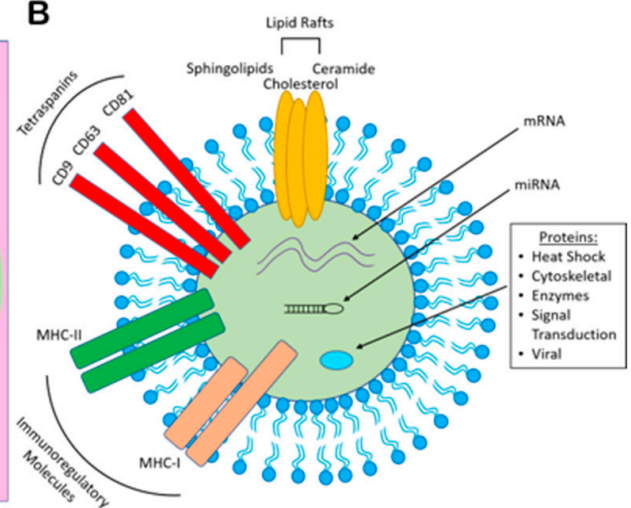

Figure 1. Size ranges of EVs and characterization. (A) Exosomes released when MVBs fuse with the PM are vesicles that range from $30-120 \mathrm{~nm}$ in diameter. Due to the similarity in size to viruses, exosomes are difficult to isolate from virus-infected blood. Microvesicles ranging from $150 \mathrm{~nm}-1 \mu \mathrm{m}$ in diameter derive via shedding/budding from the PM surface. Apoptotic vesicles released from apoptotic cells range from $1 \mu \mathrm{m}-5 \mu \mathrm{m}$ in diameter. (B) Exosomes transport a variety of proteins and genetic material. Lipid raft-derived microdomains form larger domains responsible for inducing budding in an ESCRT-independent pathway of lateral cargo segregation. Exosomes are highly enriched with tetraspanins, which play a critical role in the ESCRT-independent pathway of endosomal sorting and function as exosome-defining surface markers. Depending on the cell of origin, exosomes may contain differing immunoregulatory molecules, such as MHC-I/II. Lastly, exosomes traffic a variety of host cell/viral protein, mRNA, and miRNA.

Bridging of the exosome biogenesis and viral replication/assembly pathways depicts a shared mechanism between EV and virus particles (Figure 2). Virally infected cells release both EVs and new virions simultaneously [1]. Post-infection, viral RNAs in the cytoplasm, interacting with other viral factors undergo Gag-mediated virion assembly at the PM or close to the MVB [1]. EV or virion-containing MVB employs SNARE/SNAP Rab27 to fuse with the PM, releasing both EVs and virions [1]. Exosome-specific proteins are sorted and then transported to ILVs, where exosomes acquire their contents and are excised within the MVB [3]. Mono-ubiquitinated cytosolic domains in these exosome-specific proteins serve as sorting signals to ILVs and capturing sites for the endosomal sorting complex required for transport (ESCRT) [3]. ESCRT-0, ESCRT-I, ESCRT-II, and ESCRT-III compose the ESCRT protein machinery required for sorting the ubiquitinated cargo to the ILVs. This sorting is initiated by the interaction of the endosomal protein's (Hrs) double zinc finger domain's binding with phosphatidylinositol 3-phosphate (PtdIns-3-P), permitting ESCRT-0 binding to the endosomal membranes and eventual recruitment cascade of ESCRT-I, which recruits ESCRT-II, resulting in recruitment of ESCRT-III [4]. ESCRT-0 concentrates all non-ESCRT-III proteins that interact with ubiquitylated cargo via their ubiquitin-binding subunits, capturing cargo after it has been concentrated by [6]. The captured cargo is driven into ESCRT-III filament produced invaginations, deubiquitinating the cargo, and excising the cargo-filled ILV [6]. Several reports describe alternative pathways. For example, ESCRT-independent EV generation was observed in oligodendrocytes, where ceramide is released from the breakdown of sphingolipids and promotes domain-induced budding of the ILVs [9]. This proposed ESCRT-independent pathway is dependent on lateral cargo segregation via lipid-raft-derived microdomains, which then merge into larger domains, inducing budding [9]. Inhibition of sphingomyelinases, which hydrolyze sphingomyelin into ceramide, have been observed to inhibit exosome release but promote microvesicle secretion from the PM, showcasing that ceramide is critical for exosome formation [10]. Although EVs share a common biogenesis pathway, EV content differs depending upon the cellular source and health status. 


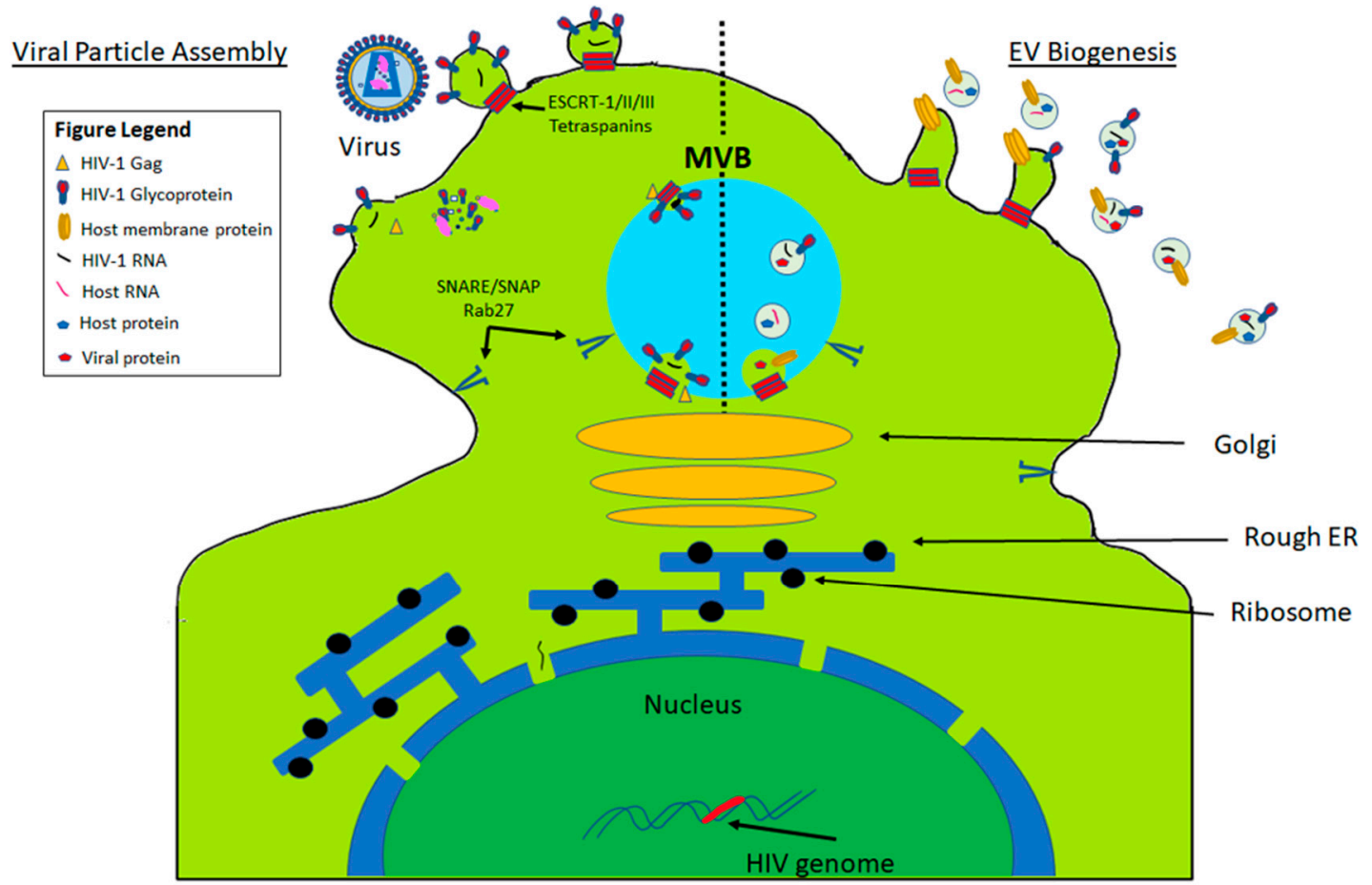

Figure 2. Comparison of viral and EV biogenesis. Infected cells concurrently release EVs and retroviral particles, possessing shared pathways at the MVB and the PM, whilst incorporating SNARE/SNAP Rab27 and tetraspanins, and ESCRT proteins in both pathways [1]. Depicted here is: sorting and transport of the exosome-specific proteins to the nascent ILVs, and excision from the MVB, Gag-mediated virion assembly at the PM or the MVB, and EV and virion release, [1,3].

\section{Isolation of EVs}

Various methods used for EV isolation include differential ultracentrifugation, immunomagnetic-bead separation, density gradient centrifugation, chromatography, precipitation-based separation, ultrafiltration, nanoplasmon-enhanced scattering (nPES), and on-chip exosome isolation Yu LL et al. [11] 2018. The most commonly used method and the gold standard in EV isolation is differential ultracentrifugation Livshits MA et al. [12,13] 2016, Jeppesen DK et al. [12,13] 2014].

\subsection{Differential Centrifugation-The Gold Standard}

For differential centrifugation (DC), the exosome EVs are separated from macromolecular proteins, apoptotic bodies, cell debris, and cells by a series of increasing centrifugations at $4{ }^{\circ} \mathrm{C}$ culminating with ultracentrifugation at $100,000 \times g$ Szatanek R et al. [14] 2015. Briefly, samples are precleared by a series of low-speed spins, first $300 \times g$ to pellet cells, then $2000 \times g$ to pellet debris, and lastly, $10,000 \times g$ to remove the macroparticle within the supernatant. Finally, The precleared supernatant is ultracentrifuged at $100,000 \times g$ for $70 \mathrm{~min}$. The pellet from the ultracentrifugation step results in the EV(exosomes) pellet. Given the overlap in the size of exosomes and microvesicles size, the EV pellet likely consists of both vesicle types. DC may be useful in isolating exosomal EVs but can be labor-intensive and time-consuming with a low yield. Despite these disadvantages, DC is considered the gold standard for exosome isolation.

\subsection{Immunoaffinity}

Immunoaffinity isolation of exosomes from tissue culture media or sera can be done via immunomagnetic-beads coated with monoclonal antibodies specific for tetraspanins, such as CD81, CD9, and CD63, found on the exosome surface Konadu KA et al. [15,16] 2016, Tauro BJ et al. [15,16] 2012. After the sample has been incubated with the antibody-labeled magnetic beads, the exosome-antibody-bead 
complexes formed are added to the separation column and retained in the column upon applying the magnetic field. This method may compromise the captured exosome integrity but assures highly purified exosomes, unlike the DC method. The primary disadvantage of immunoaffinity is the inability to separate the beads from the exosomes, thus preventing or limiting downstream applications.

\subsection{Density Gradient-OptiPrep ${ }^{\mathrm{TM}}$}

Constituents within the culture medium or serum/plasma samples are separated based on the isodensity zones formed during ultracentrifugation for density gradient-based EV isolation. The samples are layered on top of the density-gradient solution and ultracentrifuged at $10,000 \times \mathrm{g}$. This ultracentrifugation separates exosomes from the other sample constituents based on density and size Whiteside TL [17-19] 2018, Kamerkar S et al. [17-19] 2017, Lobb RJ et al. [17-19] 2015. The most commonly used solution for this method is either iodixanol (OptiPrep ${ }^{\text {TM }}$ STEMCELL Technologies, Vancouver, BC, Canada) or a 30\% sucrose solution. Samples layered at the top of a 30\% sucrose, or iodixonal solution are ultracentrifuged, at $100,000 \times g$ for $16-18 \mathrm{~h}$ yielding exosomes at a characteristic banding density zone. This method results in exosome isolations of higher purity as a result of greater separation efficiency. However, the resulting yield, similar to DC, is low.

\subsection{Chromatography}

Chromatography can also be used to obtain exosomes uniform in size and of high purity. Particles within the sample are separated through the filtration column at differing rates via centrifugation of the column. Separation of the EV particles is based on the gel pore size and EV particle size Szatanek R et al. [14] 2015. However, this method yields a paltry exosome yield and requires high-priced specialized laboratory equipment.

\subsection{Precipitation}

Precipitation-based exosome extraction methods, such as ExoquickTM (System Biosciences) total exosome isolation (Sigma Aldrich, St. Louis, MO, USA), are commercially available. These methods are now commonly used to isolate exosomes from small volume samples Alvarez ML [20] 2012. Upon mixing the sample with the precipitating solution, a polymeric ionic web captures exosomes, which are then pelleted by centrifugation. This method grants extreme ease as it is simple to perform, quick, requires only a simple centrifuge, and provides exosomes uniform in size. However, the exosomes may be contaminated with microvesicles and proteins, impairing analysis, and potential downstream use. For the precipitation reagents, the reagent itself is expensive. Each vial usable only for a small number of samples, limiting its use due to the financial strain on research funding.

\subsection{Ultrafiltration}

Exosomes may also be separated from EVs using ultrafiltration to isolate exosomes within a sample. They pass through filters with increasingly small pore size, which traps particles of higher molecular mass and allows EV exosomes and other nanoparticles to flow through Bhattacharjee C et al. [21] 2002. This method can be accomplished using either ultracentrifugation or stirring, with the latter providing the benefit of a decreased pressure on the exosomes. Exosomes maintain their integrity during the ultrafiltration process, which is less time consuming and results in a higher exosome yield without the risk of exosomal aggregation. However, just as with the other techniques, there is likely microvesicle contamination resulting in reduced exosomal sample purity.

\subsection{Nanoplasmon-Enhanced Scattering (nPES)}

Antibodies against exosomal markers, such as CD81, are used in nPES to detect and capture exosomes, similar to an enzyme-linked immunosorbent assay (ELISA). A sensor chip with a silica surface conjugated with anti-tetraspanin antibodies captures the exosomes, which are then bound by antibody-coated 
gold nanoparticle probes (GNPs), forming complexes of exosomes and GNPs Rojalin T et al. [22] 2019. Exosome quantity is measured via dark-field microscopy. However, the analysis may require complex statistical tools, and exosomal protein detection may be costly. Regardless, nPES is a quick, sensitive, and high-throughput method of detecting even trace amounts of exosomes from samples.

\subsection{Lab-On-Chip Exosome Isolation}

Lab-on-chip devices, such as the exosome total isolation chip (ExoTIC), can extract exosomes via filtration, yielding purified, and enriched exosomes Liu F et al. [23] 2017. ExoTIC provides a quick, easy to use, scalable, and affordable method of generating a high yield of patient-derived exosomes, employed in downstream applications, disease diagnosis, and point-of-care testing.

Taken together, a multitude of methods are currently available for exosome isolation allowing for different degrees of purity and subsequent downstream application. As the exosome research field continues to grow, the exosome isolation techniques will also improve, allowing for development of second and third generation techniques for high yield and pure exosome isolations.

\section{Exosomal Content and Characterization}

Exosomal EVs are enriched with the protein superfamily consisting of four transmembrane domains, tetraspanins, which form tetraspanin-enriched microdomains (TEMs) impacting exosome content, EV binding and uptake by target cells, EV biogenesis, and exosome antigen presentation [11]. Tetraspanins, including CD9, CD63, and CD81, are highly enriched within the exosomal membrane and serve as excellent exosomal biomarkers [11]. TEMs assemble the proteins and facilitate the protein-protein interactions required for ILV formation, and therefore offer another ESCRT-independent mechanism of EV generation [12]. Various intracellular vesicular trafficking steps, such as trafficking and budding of vesicles, vesicle docking, and membrane fusion, are controlled by the RAB family of small GTPase proteins [13]. Endosome-associated RAB GTPases have been observed in exosomes [14]. Inhibition of either RAB35 or RAB11 impaired exosome secretion in cells bearing the proteolipid protein (PLP) exosome biomarker or the heat shock cognate (Hsc70) chaperone protein, respectively [15,16]. Additionally, the absence of RAB2B, RAB51, RAB9A, RAB27A, or RAB27B in HeLa cells, via knock-out, results in exosome secretion inhibition demonstrating that these RAB GTPases are required for exosome biogenesis $[17,18]$. Exosome biogenesis and autophagy have an inverse relationship $[18,19]$. Lastly, exosome cargo-protein, RNA, and miRNA depends on cellular status and derivation. Viral infection modulates exosome content and may play a role in the associated viral pathology $[6,18,19]$.

\section{Role of EVs in the Pathogenesis of Viral Infections}

EV-mediated modulation of the immune system has been well studied. EVs can present antigens, trigger production and release of inflammatory cytokines, and promote cancer metastasis or induce anti-tumor responses [20-25]. There is also data indicating an interaction between EVs and viral infection. For example, EVs may facilitate viral replication and transmission by functioning as carriers of viral genetic elements, viral proteins, or regulatory elements [26]. EV biogenesis facilitates viral spread when the following conditions are met: (1) Viral proteins or RNA must reach the ILVs; components of Dengue virus (DENV), vesicular stomatitis virus (VSV), and hepatitis C virus (HCV) have all been identified in ILVs [6]. (2) Exosomes must interact with target cells releasing their infectious cargo into the extracellular space; recipient cells receive both viral and exosome constituents upon exosome entry into the cytoplasm. This condition is demonstrated by exosomes derived from HCV-infected human hepatoma cells that transport the viral envelope and core proteins alongside a full-length viral RNA [6,27]. Here we reviewed the role of EVs in the dissemination and pathogenesis of select viruses causing disease in humans. 


\subsection{Picornaviridae and Togaviridae}

Hundreds to thousands of coxsackievirus, rhinovirus, or poliovirus are packaged within phosphatidylserine (PS) lipid-enriched vesicles. This packaging enables the collective transfer of multiple viral genomes to a single cell, enhancing viral replication and enabling viral quasi-species genetic cooperativity [28,29]. To spread infection, coxsackievirus B1 must induce host cell lysis [30]. However, given that EVs may carry a replication-competent viral genome or proteins, coxsackievirus B1 can spread via EVs. Evidence suggests the intercellular transmission of coxsackievirus B1 via the increased microvesicle release induces an elevation intracellular calcium concentration, resulting in depolymerization of the host's actin cytoskeleton, a possible non-lytic cell-cell strategy to perpetuate infection [30]. Additionally, infectious virions may be transported to adjacent cells via apoptotic bodies, enhancing viral spread [3]. Pharmacologically blocking the generation of Chikungunya virus-induced apoptotic bodies in infected HeLa cells restricts viral spread to nearby cells, demonstrating the potential of hijacked apoptotic bodies in enhancing viral propagation [3].

\subsection{Herpesviridae}

EV cargo has been shown to contain several viral factors involved in viral dissemination and transmission. Exosomes transport Herpes simplex virus 1 (HSV-1) miRNA and mRNA, and potentially suppress viral reactivation to facilitate viral transmission to a new host [31]. Epstein-Barr virus (EBV), ubiquitous in humans, is a $\gamma$-herpesvirus associated with epithelial and lymphoid malignancies, a potential generator of auto-antibodies, and responsible for infectious mononucleosis [32]. Exosomal EVs derived from EBV infected B-lymphocytes release exosomes carrying MHC II molecules. Given the B-cell role in antigen presentation, these B-cell-derived EVs could activate CD4+ T-cells [6,25]. EBV-infected nasopharyngeal carcinoma cell release exosomes deliver a CD4+ T-cell apoptosis inducer and immunoregulator protein galectin-9, to evade the host immune response $[6,33,34]$. Natural killer (NK) cell cytotoxicity, IFN- $\gamma$ production, and T-lymphocyte activation and proliferation is known to be inhibited by the latent membrane protein 1 (LMP1) of EBV; a viral oncogene commonly detected in EBV-associated tumors. Interestingly, LMP1 was found in the exosomal cargo of theses EBV-associated tumors, thereby supporting the concept that EVs play a role in facilitating viral host-immune response evasion strategy $[6,33,35,36]$.

\subsection{Filoviridae}

Infection with the ssRNA, negative sense Ebola virus (EBOV) results in systemic infection with severe hemorrhagic fever, immune suppression or overactivation, and tissue damage [37-39]. Upon infection, EBOV primarily targets dendritic cells, monocytes, and macrophages, potentially facilitating systemic virus spread, including liver and secondary lymphoid organs [40]. Given the symptoms mentioned above and the high mortality rate of $80-90 \%$, Ebola patients' rapid identification is necessary [41]. A commonly applied technique for diagnosing Ebola patients is the detection of VP40, the EBOV matrix protein [39]. VP40 may employ two methods to release from cells, independent budding from cells or exosomal incorporation [39]. This transportation of VP40 into the nucleus facilitates EV synthesis regulation via over-transcription of cyclin D1 by binding VP40 to cyclin D1's promoter, dysregulating the cell cycle [39]. Additionally, the VP40-laden exosomes exert a dose-dependent decrease in cellular viability of recipient monocytes and T-cells; and these exosomes contained cytokines, which may contribute to EBOV pathology [39].

EBOV pathology is further enhanced by exosome-bound VP40 modulating RNAi components, such as Dicer and Ago 1, and inducing recipient naïve cell death while upregulating exosome biogenesis [41]. EBOV content release is not limited to exosomes but extends to microvesicles as well [38]. Microvesicles containing EBOV glycoproteins (GP) have been linked to increased pathogenicity and immune evasion [38]. 


\subsection{Paramyxoviridae}

Respiratory syncytial virus (RSV) causes acute respiratory tract infections in the elderly, children, and immunocompromised individuals, resulting in an estimated 200,000 deaths annually [42]. To better understand RSV pathology and developing a vaccine, exosomal cargo during RSV infection was characterized [42]. Although the exosomes contain RSV components, such as the RSV nucleocapsid protein $\mathrm{N}$, infectious RSV particles were undetected in exosomes, and the exosomes containing $\mathrm{N}$ were unable to infect cells. However, exosomes did exhibit significant changes to RNA composition that resulted in chemokine release [42]. The miRNA and piRNA content of exosomes generated from RSV infected cells was significantly modulated [42]. Some of the miRNA content was expressed at a significantly higher level within exosomes generated from RSV infected cells than uninfected cells [42]. Exosomes derived from RSV infected cells induce exposed human monocytes to secrete proinflammatory mediators, such as IP-10, RANTES, and MCP-1 [42].

Additionally, exosome-bound RNA cargo was protected from degradation, and the RNA subtype proportions were significantly modulated by RSV infection; of note, the upregulation and downregulation of miRNAs [42]. RSV infection in patients with cystic fibrosis is associated with coinfection with the opportunistic pathogen Pseudomonas aeruginosa [M1] [43]. The [AR2] shift from an acute $P$. aeruginosa infection to a chronic state is dependent on the formation of a biofilm with antibiotic properties, within the lung, which facilitates disease progression [43]. Infection with RSV promoted exosome-bound transferrin secretion, an iron-binding protein found in the host, known to promote P. aeruginosa biofilm growth [43]. This transferrin secretion demonstrates the capacity of RSV to facilitate the persistence of pathogens within the airway epithelium via exosomes [43]. However, exosomes may also facilitate the host immune response upon Influenza A virus (IAV) infection. Human tracheobronchial epithelial cells traffic components of the innate immune response, such as MUC1, MUC4, and $\alpha-2,6-$ linked sialic acid via exosome-like vesicles [44].

\subsection{Orthomyxoviridae}

Influenza A viruses pose a threat to humans worldwide, causing outbreaks of acute respiratory tract infections and seasonal epidemics [45,46]. About 36,000 individuals die as a result of flu-associated infections annually in the US [45]. Intercellular communication via exosomal miRNAs may modulate cell function, alter recipient cell pathways, and facilitate viral persistence [45-48]. IAVs have been found to alter circulating miRNAs within exosomes, potentially promoting viral pathogenesis $[49,50]$. For example, IAV-infected human lung adenocarcinoma epithelial A549 cells produced exosomes containing miRNA hsa-miR-1975, which inhibited IAV replication by inducing interferon production [51]. IAV modulation of exosomal cargo is not limited to miRNAs, as autophagy-related proteins, including Atg3/7 and antiviral cytokines such as IL6, IL18, and TNF, are found in exosomes released from IAV-infected macrophages [52]. This finding demonstrates IAV capacity to alter macrophage-dependent innate immune responses and intercellular cell signaling via manipulation of exosomal cargo. Pathogens may also transport viral components within exosomes, such as transportation of IAV progeny RNA to the apical side of the membrane by attaching to Rab11 vesicles, thereby facilitating late-stage IAV budding and infection $[6,53]$. Applying LC-MS/MS in proteomic studies have discovered that IAVs integrate exosomal proteins or markers such as annexin A3, CD9, CD81, and ICAM1, contributing to the influenza virion structure, viral spread, and implying a shared formation pathway with exosomes [54].

\subsection{Hepadnaviridae}

Hepatitis B virus (HBV) infects human hepatocytes leading to liver fibrosis, cirrhosis, and eventually hepatocellular carcinoma $[55,56]$. HBV's HBx protein facilitates oncogenic activities via various mechanisms such as host gene stimulation, cell cycle interference, and mitogenic signaling [55]. Both HBx protein and associated mRNA encapsulated within exosomes released from HBV infected cells into the extracellular environment, permitting horizontal transfer of its gene products and viral 
protein expression [55]. HBx containing exosomes have significantly different cargo, both quantitatively and qualitatively [55]. These altered exosomes promote HBV-associated liver diseases by inducing proliferative signaling and enhancing exosome biogenesis via increasing neutral sphingomyelinase 2 activity [55]. The natural killer group 2D (NKG2D) receptor recognizes ligands on infected cells, promoting innate immunity and lymphocyte activation to defend the host from infections [57]. Exosomes generated from HBV infected cells contain viral RNA that induces expression of the NKG2D ligand in macrophages, implying a role for HBV-infected cell-derived exosomes in NK cell activation. The upregulation of CD69 confirms the exosome role in modulating NK cell activation and inducing IFN- $\gamma$ production, which leads to the degradation of viral RNA in hepatocytes [56].

Furthermore, infection with HBV increased immunosuppressive miRNAs: miR-21 and miR-29a, within CD81+ exosomes and EVs, transferred from hepatocytes to macrophages [56]. Downregulation of IL-12p35 and IL-12p40 occurs as a result of miR-21 and miR-29a expression, respectively. The increase in these miRNAs potentially inhibit NK cell activity via IL-12 downregulation and facilitating viral evasion of the host immune response [56]. Another study concluded through proteomic analysis of exosomes via LC-MS/MS that HBV-infected HepAD38 hepatoblastoma cell line-derived exosomes contain HBV-associated proteins capable of significantly reducing monocyte IL-6 production [58]. HBV infection in HepAD38 cells alters 35 exosome-bound proteins, including the increase of five proteasome subunit proteins: PSMD1, PSMD7, PSMD14, PSMC1, and PSMC2, enhancing proteolytic activity [58]. Inhibition of exosome-dependent proteasomal activity resulted in increased IL-6 production, implying proinflammatory molecules modulated by proteasomal subunit proteins within HepAD38 exosome transport [58]. Exosomes transfer HBV proteins and genetic content to other cells. For example, NK cells and hepatocytes of chronic HBV patients release exosomes that contain HBV proteins and nucleic acid [59]. Uptake of these exosomes impairs NK cell production of IFN- $\gamma$, NK cell survival and proliferation, cytolytic activity, and NK cell responsiveness to poly (I:C) stimulation [59]. The exosome role in HBV infection is not limited to facilitating viral replication. IFN- $\alpha$ induced HBV antiviral activity is transferred via exosomes from liver non-parenchymal cells (LNPCs) to hepatocytes [60].

\subsection{Flaviviridae}

Currently, there is no vaccine against $\mathrm{HCV}$, a +ssRNA flavivirus that is one of the leading causes of liver disease worldwide [61]. Sera from HCV-infected patients and supernatants of J6/JFH1, an HCV-infected Huh7.5 cell line, contain exosomes with HCV RNA, proteins, and particles [61]. Viral genome packaging in exosome is not limited to the Picornaviridae, HCV-infected hepatocytes release full-length genomic HCV RNA laden exosomes that can activate immune cells and establish a productive infection in naïve human hepatoma cells to facilitate viral spread [62]. Human Ago2 and miR-122, necessary for HCV RNA accumulation and translation, have been detected within exosomes derived from HCV-infected patient serum or J6/JFH1-HCV-infected Huh7.5 cells. This demonstrated the exosome capacity to enhance viral spread via transport of viral regulatory elements $[61,63]$. EVs are also capable of transmitting Flaviviruses from arthropod vectors to humans by acting as carriers [18].

Arthropod-borne neurotropic encephalitis viruses replicate within the peripheral tissues and blood of a vertebrate host after transmission, cross the blood-brain barrier (BBB), and infect the central nervous system (CNS) [64]. Langat virus (LGTV)-infected Ixodes scapularis ISE6 tick cells release EVs, which mediate the transmission of viral RNA, envelope protein, and non-structural 1 (NS1) protein from arthropod to human cells [64]. These insect-cell derived exosomes are also delivered upon infection of naïve human skin keratinocytes (HaCaT cells), the barrier that first contacted the tick bites [64]. LGTV infects murine brain endothelial barrier (bEnd.3) cells, and the endothelial cells produce exosomes, which transmit infectious RNA and proteins to murine neuronal (N2a) cells [64]. LGTV infected neuronal cells further disseminate the virus within the brain via exosomes resulting in neuronal loss and neuropathogenesis [64]. 


\subsubsection{ZIKA}

To date, few studies have demonstrated that exosomes are integral to the interaction between ZIKV and host cells. ZIKV and Zika viral proteins have been detected in the eyes and semen, months after initial infection, thus creating a need to comprehend how these particles persist and damage neuronal cells. Exosomes can easily cross the endothelial barriers protecting these sites and therefore are a potential antigen source [65]. Additionally, precedence for modulating EV contents by ZIKV exists, as other flaviviruses have been observed to do so [65]. Here this review summarized the role of EVs in the context of ZIKV infection.

ZIKV has been demonstrated to cross the placental barrier (PB), detecting ZIKV in the fetal brain and amniotic fluid confirming ZIKV tropism for neuronal tissue [66-68]. Infection of the fetal brain with ZIKV may result in severe congenital malformations, also known as ZIKV fetal syndrome [66-68]. Individuals with ZIKV fetal syndrome may present with several congenital disabilities, including but not limited to: facial disproportionality, microcephaly, hypertonia, cutis gyrata, ventriculomegaly, and a lack of brain tissue [68]. It is believed that after crossing the placenta, ZIKV damages neuronal cells and induces the immune response [68]. Although the exact mechanism for ZIKV passage through placental trophoblasts is unknown, ZIKV, like DENV, may employ the placental exosome pathway at the trophoblast ER for this purpose, as it is strongly associated with the process of secretory autophagy [66]. Immature ZIKV viral particles translocate to the trans-Golgi network, from the ER [67]. ZIKV may be vertically transmitted independently of the secretory autophagy pathway due to increased permeability resulting from ZIKV-induced damages and apoptosis of placental cells [66]. Studies indicate a role for autophagy in ZIKV-associated neuropathology, as inhibition of autophagy results in inhibition of ZIKV replication [68].

Uninfected human placental trophoblast (HPT) cells secrete type-III IFNs, IFN $\lambda 1$ and IFN $\lambda 2$, conferring anti-ZIKV protection [69]. Syncytiotrophoblasts constitutively generate IFN $\lambda 1$, providing an antiviral state protecting placental cells in an autocrine manner and non-placental cells in a paracrine manner [69]. Non-placental cells may be protected and establish an antiviral state via exposure to HPT-derived conditioned media (CM) [69]. This data suggests that ZIKV replication within placental syncytiotrophoblasts permitting access to the fetal compartment is not possible without either ZIKV evasion of the IFN type III antiviral properties or bypassing the PB via an unknown pathway, possibly EV-mediated [69].

\subsubsection{EV-Mediated Restriction of ZIKV Pathogenesis}

Exosomes and microvesicles are released into maternal blood during pregnancy. They can be recovered during the first and second trimester of pregnancy, increasing in concentration with the progression of the pregnancy [70]. These exosomes have been found to contain primate-specific chromosome 19 cluster (C19MC) miRNAs functioning as antiviral agents, which may be transferred to non-placental cells, conferring protection and upregulating autophagy upon the target cells if delivered via exosomes generated from trophoblasts [70,71]. EVs carrying MIR517-3p, MIR16B-5p, and MIR512-3p induced potent antiviral activity in recipient cells [70]. Additionally, HPT-derived exosomes carry miRNAs conferring viral resistance to non-placental recipient cells [71]. The miRNAs of C19MC attenuated ZIKV infection in non-HPT cells, however, they fail to activate IFN-stimulated genes [72]. Together, this data demonstrates the potential anti-ZIKV properties of HPT-derived exosomes, acting in an IFN-independent manner.

ZIKV infection of astrocytes significantly increases EV biogenesis, predominantly composed of microvesicles and exosomes [73]. Additionally, significant variation of miRNA transcripts expression has been observed in HPTs following permissive replication of ZIKV. For example, downregulation of miR-21, known to cause TLR7-mediated neurotoxicity [74,75]. This data presents with an apparent anti-ZIKV host cell response transported via exosome-trafficking.

Inhibition of ZIKV infection by EVs derived from the semen of a ZIKV-infected patient has been observed [76]. Although freshly derived ZIKV-infected patient semen efficiently blocked ZIKV-MR766 
infection of Vero E6 cells, the nature of the antiviral component responsible for this inhibition remains unknown [76].

\subsubsection{EV-Mediated Enhancement of ZIKV Neuropathology}

Upon infection with ZIKV, macrophages, which are permissive to ZIKV infection, are recruited and amplify ZIKV replication [77]. The exosomes generated from the activated macrophages are transported to the human placenta, leading to the induction of placental pro-inflammatory cytokine production [78]. In combination with ZIKV NS5-mediated activation of NLRP3, inducing stimulation of human macrophage IL-1 $\beta$ secretion, which results in the host inflammatory response, macrophage recruitment promotes inflammation, a major determinant of ZIKV pathogenicity [79].

A murine study has shown that exosomes facilitate the transmission of ZIKV across neurons by functioning as mediators [80]. An increase in exosome biogenesis was recorded in mouse cortical neuronal cell-derived exosomes alongside the detection of ZIKV-RNA and envelope (E) protein [80]. Furthermore, neutral sphingomyelinase (nSMase)-2/SMPD3 gene expression and activity was induced by ZIKV [80]. SMPD3 regulates exosome generation and release [80]. Exosome-mediated viral transmission rate and burden were reduced after the silencing of SMPD3 in neuronal cells; a similar effect occurred upon exposure to GW4869, an inhibitor specific to SMPD3 [80]. This study suggests that modulation of SMPD3 activity resulting from ZIKV cortical neuron infection is integral towards viral infection and exosome-mediated transfer resulting in ZIKV-associated neuropathology, such as microcephaly, as a result of severe neuronal death [80]. At this time, there are not many clinically relevant interactions between EVs and ZIKV are known; research is ongoing (Figure 3). Unlike ZIKV, however, a greater volume of EV-mediated effects on HIV-1 pathogenesis has been studied.
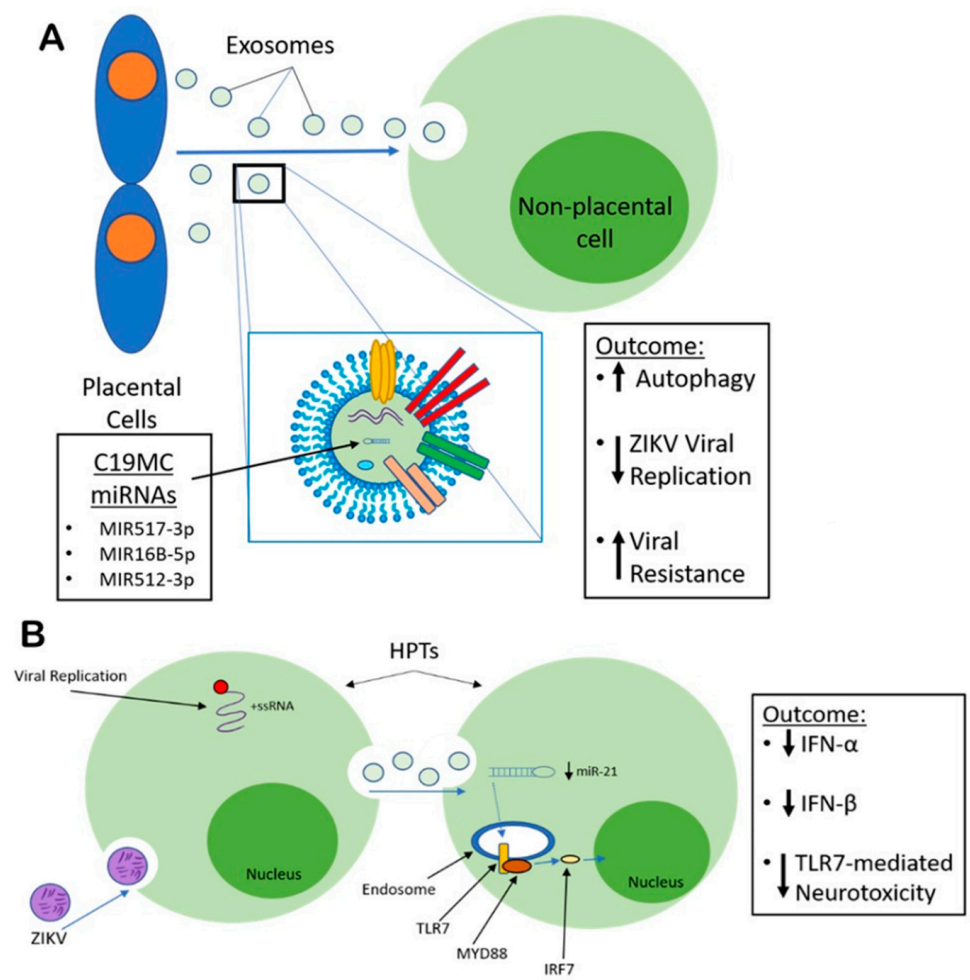

Figure 3. EV-mediated anti-ZIKV effects. (A) HPT cell-derived EVs bound with miRNAs with potent anti-viral properties, have been detected. The EVs migrate to non-placental recipient cells conferring anti-ZIKV protection and up-regulating autophagy. (B) ZIKV infection of HPT cells results in an anti-ZIKV host-cell response transported via exosome-trafficking, downregulating miR-21 in uninfected HPTs, reducing TLR7-mediated Neurotoxicity. 


\subsection{Retroviridae}

\subsubsection{Human Immunodeficiency Virus Type 1 (HIV-1)}

HIV-1 targets both macrophages and T-lymphocytes via the primary receptor CD4 and coreceptors CCR5 or CXCR4, thus inducing apoptosis of CD4+ receptor T-lymphocytes and weakening the host immune system [81,82]. With over 75 million infected individuals worldwide, HIV remains an epidemic and one of the most significant causes of morbidity and mortality [82]. Even though antiretroviral therapy (ART) successfully restricts HIV-1 infection, often reducing viral loads below detection, challenges continue [18,82]. Retroviruses are unique in that they have both lytic and latent life cycles. ART is not curative due to either the failure to eliminate latent virus reservoirs, treatment toxicity, viral mutations, or divergent patient responses to HIV infection, therapies, or adherence [18,82]. Therefore, comprehending the HIV-1 interaction with immune cells is integral to elucidate novel aspects of HIV-1 disease, which could be developed as therapeutic targets [18,82].

HIV-1 particles and exosomes share some molecular properties of biogenesis, and cellular uptake mechanisms, all of which are beyond this review [18]. There are critical points in the viral assembly that intersect EV biogenesis; therefore, exosomal EVs play a crucial role in HIV-1 pathogenesis [83]. This indicates potential roles for exosomes in HIV-1 pathogenesis, which is covered here [18].

\subsubsection{EV Interaction with Host Cell Restriction Factors and HIV}

EVs contribute to antiviral responses by delivering host-derived restriction factors to nearby cells. For example, the host cell viral restriction factor cellular cytidine deaminase APOBEC3G (A3G) is contained within CD4+ T-cell derived EVs. A3G inhibits HIV-1 replication by interfering with HIV-1 reverse transcription in a deamination-dependent and deamination-independent manner, catalyzing hypermutation of the viral DNA [84-86]. However, this effect is not observed in vivo, as A3G is depleted post-HIV-1 infection, leaving an insignificant quantity of EV-bound A3G incapable of having an antiretroviral impact $[18,86]$.

CD4+ T-lymphocytes release exosomes with CD4 on the surface, thereby competing with cells for binding to HIV-1 virions. The CD4+ EVs can potentially restrict HIV in several ways: acting as a decoy for CD4+ T-cells, neutralizing HIV-1 virions, or protecting neighboring T-cells from infection, ultimately inhibiting HIV-1 spread. These effects of CD4+ exosomes can be countered by the HIV-1 accessory protein, Nef, which reduces CD4 expression in T-cells [18,87]. CD4+ EV effects suggest that CD4+ T-cells utilize exosomes to protect against HIV-1 infection, indicating a role for EVs in antiviral immunity.

\subsubsection{Immune Cell-Derived EVs and Antiviral Effects}

Similar to CD4+ T-cells, CD8+ T-cells release exosomes that restrict HIV-1 replication. CD8+ T-cell-derived EVs contain an anti-HIV protein moiety that suppresses replication without EV internalization. This indicates that exosome-mediated HIV-1 transcription suppression may comprise of an intracellular signaling pathway [88]. EVs contain components of toll-like receptor (TLR) innate antiviral pathways. TLR3-activated human brain microvascular endothelial cells (HBMEC) release EVs that block HIV-1 infection to the CNS via transport of antiviral factors and IFN-stimulated genes (ISGs), thereby transferring anti-HIV protection to macrophages [89]. Macrophage and CD4+ T-cells, enriched in the gastrointestinal system (GI), are protected against HIV-1 by EVs released from TLR3-activated intestinal epithelial cells (IECs) containing HIV-restriction miRNAs (miRNA-20 and miRNA125b) and ISGs (ISG15, OAS-1, and Viperin) [90]. These mechanisms demonstrate that EVs interact with cellular barriers (BBB/GI) via TLR pathways to promote innate antiviral immunity [89,90].

EVs are found within most bodily fluids, including blood, breast milk, semen, and vaginal fluids, hindering HIV-1 infection throughout the body [91-95]. Vertical transmission of HIV-1 can be inhibited by breast milk-derived EVs that bind DC-SIGN receptors, thereby preventing HIV-1 from binding and potentially inhibiting HIV interaction with monocyte-derived dendritic cells 
(MDDCs) and HIV-1 transfer to CD4+ T-cells [94]. Sexual transmission of HIV-1 is inhibited by EVs derived from uninfected semen or vaginal fluid-derived EVs, negatively affecting reverse transcriptase activity [92,93]. Heterosexual transmission of HIV-1 is facilitated by vaginal epithelial cells (VECs) uptake of semen-derived EVs containing functional viral mRNA, enabling viral spread, as evidenced in a murine AIDS model [92]. However, in a human transwell model using VECs, semen-derived EVs inhibited HIV-1 spread [92]. EVs play a dichotomous role in modulating HIV-1 transmission, restricting and enhancing viral spread $[93,94]$.

\subsubsection{EV-Mediated Enhancement of HIV-1 Infection}

EVs also enhance HIV-1 pathogenesis and infection [18]. HIV-1 infection/pathogenesis disrupts the endomembrane system and modulates EV cargo, biogenesis, targeting, and/or release frequency [18]. For example, PBMCs release microvesicular EVs containing CCR5, transporting them to neighboring cells deficient in CCR5, enhancing cellular susceptibility to HIV-1 [96]. Megakaryocytes release EVs containing CXCR4, delivering the HIV-1 coreceptor to nearby tissues lacking CXCR4 expression, facilitating viral spread $[97,98]$.

EVs also assist in HIV-1 entry by interacting with HIV-1 virions, which contain high concentrations of phosphatidylserine (PS), a hallmark of apoptosis. PS interacts with T cell immunoglobulin and mucin proteins (TIM-4), highly expressed in EVs. TIM-4 binding to HIV-1 PS surface-bound moieties results in increased exosome-mediated trafficking of HIV-1 to immune cells [99,100]. HIV-1 entry into human T-cell and monocytic cell lines can be enhanced by exosomal tetraspanins CD9 and CD81 $[99,100]$. Blocking of TIM-4 or any of these tetraspanins with antibodies, result in significant blockage of viral entry, supporting an exosome-dependent mechanism for HIV-1 entry [99,100]. TIM-4 has also functioned as an apoptotic cell phagocytic receptor due to recognizing the exposed PS moieties [101,102]. HIV-1 can evade immune surveillance by camouflaging itself within exosome aggregates, facilitating viral spread [103].

Additionally, exosomes derived from HIV-1 infected primary cells are abundant with transactivating response (TAR) element RNA, which has enhanced undifferentiated naïve cell susceptibility to HIV-1 infection [104]. Primary macrophage exposure to these HIV-1 infected cell-derived exosomes promotes macrophage release of proinflammatory cytokines, TNF- $\beta$, and IL-6, indicating EV-mediated modulation of proinflammatory cytokine gene expression [104]. EV-mediated enhancement of HIV-1 infection is not restricted to exosomes, as apoptotic bodies generated during HIV infection inhibit the function of dendritic cells (DC), resulting in decreased DC-dependent cytokine production and T/NK-cell priming via DC-CD44 receptor binding of apoptotic microvesicles [3]. Taken together, HIV-EV interactions exploit apoptotic clearance mechanisms and facilitate viral replication and host cell viral uptake $[18,101,102,105]$.

Besides facilitating viral entry, EVs transfer active HIV-1-derived molecules to bystander cells, promoting viral infection [106]. HIV-1 infected cells release EVs containing the HIV-1 envelope (Env) protein (gp120), Gag, and Nef. EVs containing gp120 significantly raise HIV-1 infectivity in lymphoid tissues [106-109]. Nef, an accessory protein responsible for modulating protein trafficking within host cells and HIV-1 pathogenicity, is known to be released within EVs [110-112]. EVs-containing Nef has been identified at high concentrations in the plasma of HIV-1 infected patients. Nef-containing EVs function to promote EV secretion, increased MVBs within cells, and induce apoptosis within CD4+ T-cells [110-113]. Given that Nef has several functions, Nef-EVs could potentially promote decay of CD4+ T-cell populations, promote CD8+ T-cell activity, CXCR4-mediated apoptosis, and ADAM17 activation, increasing CD4+ T-cell permissiveness to HIV-1 [114-118].

Viral components enhancing HIV-1 infection are not limited to viral proteins. Through coevolution with the host, HIV-1 presents with differential miRNA content relative to uninfected cells, facilitating suppression of host RNA interference (RNAi) [119,120]. EVs from HIV-1 infected macrophages and plasma contain HIV-1-derived miRNAs: vmiR88 and vmiR99, promoting macrophage release of TNF- $\alpha$ via TLR8 activation, thus supporting chronic immune activation [121]. Exosomal and cellular miRNA profiles are modulated by the HIV-1 Nef protein, affecting HIV-1 pathogenesis and viral replication 
modulated by host RNAi [122]. EV-encapsulated miRNAs can alter HIV-1 pathology and enhance an infection similar to proteins.

HIV- 1 crosses the BBB, enters the CNS, infecting astrocytes, and microglia, causing chronic neurologic disease [123]. BBB permeability and integrity are disrupted by microglia-derived Nef-EVs, which reduce zonula occludin-1 (ZO-1), lower tight junction (TJ) protein expression in HBMECs, and increase TLR-induced chemokines and cytokines [124]. This loss of BBB integrity would induce some degree of neuropathology. Nef-EVs are elevated in the plasma of individuals with HIV-1-associated neurocognitive disorders (HAND), thus suggesting a role of exosome-encapsulated Nef in HIV-1 neuropathology [110]. Overall, EVs enhance and restrict HIV-1 infection through various methods, summarized in (Figure 4).

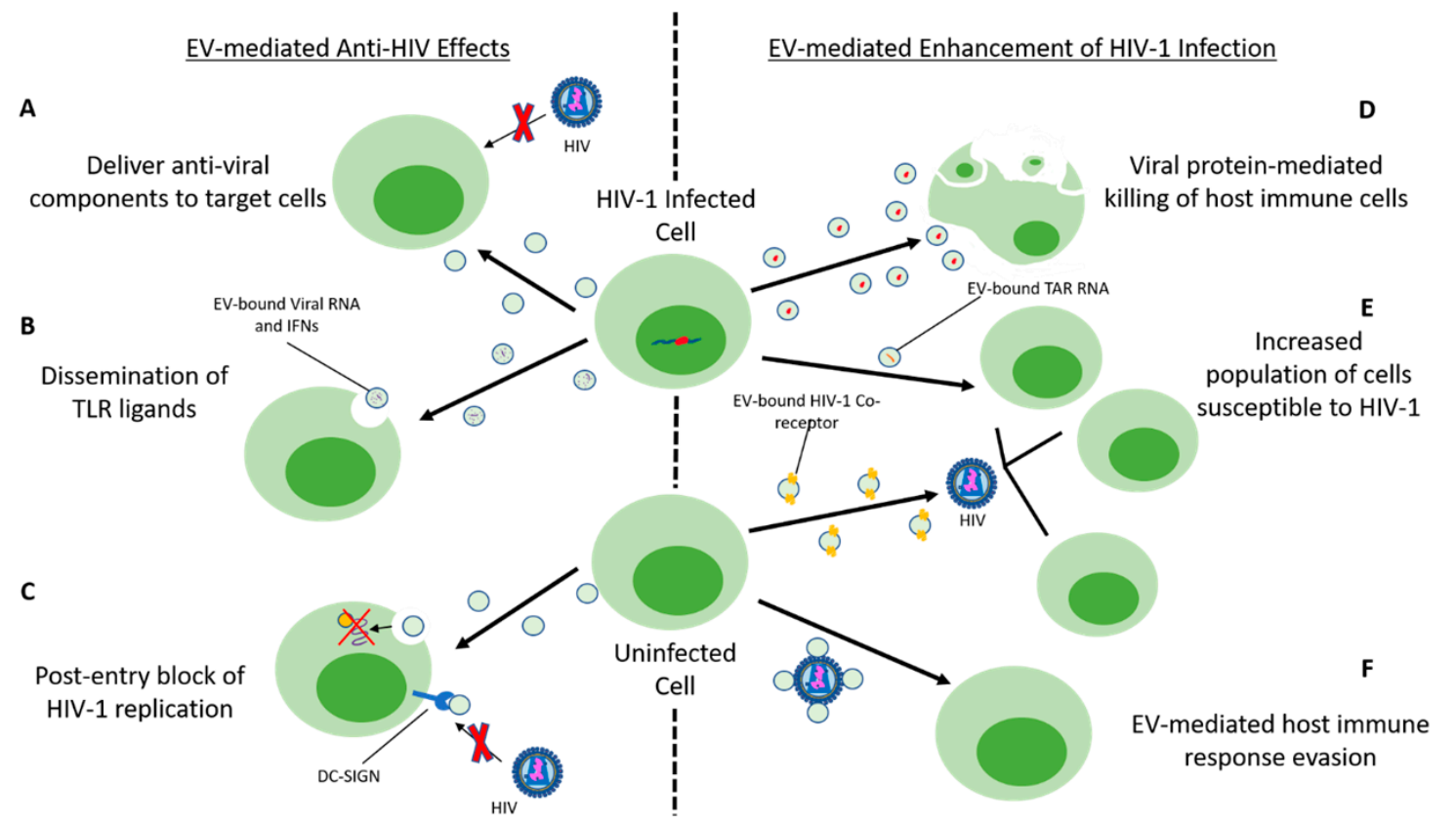

Figure 4. HIV-1 infected cell-derived EV-mediated anti-viral and pro-viral effects. Upon infection with HIV-1, cells release EVs which may modulate HIV-1 pathogenesis, either restricting infection or enhancing it. (A) EVs can deliver anti-viral particles, such as A3G, inhibiting HIV-1 replication. (B) EV-mediate dissemination of TLR ligands, including HIV-restriction miRNAs, ISGs, IFNs, and anti-viral factors transfer anti-HIV protection and alert neighboring cells of ongoing infection. (C) EVs derived from bodily fluids such as breast milk, semen, and vaginal fluids can hinder HIV-1 infection by blocking HIV-1 replication after viral entry or competing with HIV-1 for receptor access. Breast milk-derived EVs compete with HIV-1 binding to the DC-SIGN receptor, preventing vertical transmission. Internalization of either semen or vaginal fluid-derived EVs results in deleterious effects upon HIV-1 reverse transcriptase activity leading to a post-entry block of HIV-1 replication. (D) EV-mediated transport of viral particles, such as HIV-1 Nef protein, triggers viral-mediated apoptosis of anti-viral immune cells. (E) Transport of HIV-1 chemokine co-receptors CCR5 or CXCR4 via EVs to cells deficient in these receptors, generates new populations of cells which are now susceptible to HIV-1 infection. HIV-1 infected primary cell-derived EVs carry TAR element RNA, enhancing susceptibility to HIV-1 infection in undifferentiated naïve cells. (F) Lastly, EVs may aggregate upon the HIV-1 virion as a result of exploitation of exosomal surface properties, camouflaging HIV-1 and facilitating viral spread to uninfected innate and adaptive immune cells.

\subsection{Coronaviridae}

Coronaviruses belong to a family of enveloped positive-strand RNA viruses encoding a standard set of four structural proteins: the small envelope glycoprotein (E), membrane protein (M), nucleocapsid protein $(\mathrm{N})$, and the spike glycoprotein (S) [125-127]. Coronaviruses cause disease 
in humans and animals. There are four human coronaviruses 229E, NL63, OC43, and HKU1 that cause a mild illness similar to the flu with temperate systems. However, three pathogenic strains of coronaviruses cause an atypical pulmonary disease, known as severe acute respiratory syndrome (SARS), in humans SARS CoV, Middle Eastern respiratory syndrome (MERS-CoV), and now the novel SARS CoV-2 of 2019. The first SARS coronavirus outbreak with SARS CoV in 2002 has been contained primarily in China since 2003. The most recent coronavirus outbreak in 2019 is with SARS CoV-2, associated with the severe respiratory disease called Coronavirus Disease 2019 (COVID-19) and has spread beyond China's borders, becoming a public health issue and a pandemic in which many lives have been lost [125].

Exosomes transport the viral genome of SARS-CoV-2 to target cells [128]. Uptake of these SARS-CoV-2 exosomes by human-induced pluripotent stem cell-derived cardiomyocytes (hiPSC-CMs) resulted in an upregulation of genes associated with inflammation in hiPSC-CM [128]. Additionally, viral RNA fragments were detected within the hiPSC-CMs after coincubation with the SARS-CoV-2 gene overexpressing A549-derived EVs [128]. This exhibits how coronaviruses may infect target cardiomyocytes indirectly, without requiring a direct viral infection, instead of utilizing exosomes to deliver viral RNA. This is an excellent example of how coronaviruses may exacerbate pathology by altering the inflammatory state via exosomes.

Human host factor angiotensin-converting enzyme 2 (ACE2) has been identified, during the first coronavirus epidemic, as the receptor for the SARS causing coronavirus [129]. ACE2 and the DC-SIGN family of receptors bind the S protein, mediating coronavirus entry to target cells [125]. Given this most recent outbreak of coronavirus, there is an urgent need for a vaccine against this virus [125]. Given the physiological properties of exosomes, researchers have investigated the potential of exosomal vaccines [125]. Exosomes incorporated with spike S proteins results in the generation of neutralizing antibodies.

Furthermore, priming with the S-protein exosome vaccine and subsequent boosting via the addition of the adenoviral vector vaccine yielded neutralizing antibody titers exceeding those of a SARS-convalescent patient serum [125,130]. This exosome-based vaccine is an excellent example demonstrating the possibilities of exosomes as nanotherapeutics. Vaccines are not the only possibility as already clinical trials using exosomes derived from allogeneic bone marrow mesenchymal stem cells (ExoFlo) have begun [131]. ExoFlo was used to treat 24 patients, testing positive for SARS-CoV-2 via polymerase chain reaction [131]. Patients were classified with severe COVID-19 and moderate to severe acute respiratory distress syndrome (ARDS) [131]. A single dose was administered intravenously, with the $15 \mathrm{~mL}$ ExoFlo treatment being evaluated daily for 14 days [131]. Treatment with ExoFlo caused patients' oxygenation and clinical status to improve. These improvements extended to improved neutrophil counts, with a mean reduction of 32\%, and increased CD3, CD4, and CD8+ lymphocyte levels, improving patients' lymphopenia [131]. ExoFlo is a top candidate for an exosome-based nanotherapeutic for COVID19, given its overall safety, capacity to restore oxygenation, downregulate the cytokine storm, and reconstitute immune function. [131].

\subsection{Polyomaviridae}

Polyomaviruses possess icosahedral symmetry, are non-enveloped, are small at $44 \mathrm{~nm}$ in diameter, are prevalent throughout nature, are composed of 72 capsomers, and adapt to thrive in the specific tissue and species they infect [132]. There are five polyomaviruses that infect humans: Merkel cell, JC, BK, KI, and WU polyomavirus [132]. Interaction between the virion and cell surface sialic acids is responsible for virion adsorption to the cell surface and subsequent cellular infection [132]. The host cell engulfs the polyomavirus via endocytosis, allowing it to enter the cell cytoplasm and, via the cytoskeleton transport machinery, transporting the virions to the nucleus [132]. Once at the nucleus, viral DNA replication and virion progeny formation occurs [132]. The release of new virions is believed to occur via either secretion from the plasma membrane or the lysis of host cells [132]. 
The endemic JC polyomavirus (JCPyV) is observed to have established a persistent infection in the urogenital system of over $50-70 \%$ of the human population worldwide [133,134]. In immunocompromised patients, JCPyV spreads to the central nervous system, infecting oligodendrocytes, and results in rapid progression to the severely debilitating demyelinating disease: progressive multifocal leukoencephalopathy (PML) [133]. JCPyV was found to associate with EVs in addition to infecting target cells in a receptor-independent manner [133]. Viral particles have been observed to be packaged within EVs and attached to the vesicle's outer side [133]. Additionally, when cells were treated with neuraminidase, an enzyme that destroys receptors, viral infection was inhibited. However, neuraminidase treatment could not inhibit EV-associated viral infection [133]. Furthermore, cells failed to be transduced with mutant pseudoviruses, if possessing defective sialic acid receptor binding. However, when associated with EVs, cellular transduction became possible [133]. This EV-based mechanism of infection may play a crucial role in the spread and dissemination of JCPyV to and within the central nervous system [133].

In another study, JCPyV was observed to infect choroid plexus epithelial cells and then found to be contained within the EVs derived from these infected choroid plexus epithelial cells, trafficking the virus from the periphery to the brain, and subsequently transmitting the infection to human glial cells [134]. These JCPyV-containing EVs may be taken into the target glial cells via two methods: micropinocytosis or clathrin dependent endocytosis [134]. According to this data, infection of the parenchyma is crucial to viral spread to the CNS, demonstrating the potential of EVs as carriers of virions [134]. A study by Giovannelli et al. demonstrated that JCPyV-infected cell derived exosomes, carrying viral miRNAs, may be trafficked to uninfected cells [135].

Most individuals are asymptomatics carriers of BK polyomavirus (BKPyV), which is responsible for nephropathies in recipients of kidney transplants [136]. Handala et al. confirmed, via electron microscopy, that a single EV originating from an infected cell could transport dozens of viral particles [136]. Additionally, the EV-associated BKPyV employed a cellular entry pathway differring from that of a non-EV-associated virion, as the EV-associated viral particles did not attach to the cell via cell surface sialylated glycans nor were they able to agglutinate red blood cells [136]. Overall, current research suggests that exosomes provide polyomaviruses a significant increase in tropism and virulence. However, there is a lack of data describing the mechanism for polyomavirus' immune evasion and persistence [136].

\section{Therapeutic Potential of EVs as Antiviral Agents}

Exosomes are ideal therapeutic agents, as they are non-immunogenic, can pass cellular barriers, and the contents can be manipulated. Exosomes can be used as delivery systems to transfer pharmaceutical drugs, proteins, enzymes, antibodies, and other biologically relevant molecules to target cells [137-139]. Since exosomes possess a unique biologic potential for biomedical applications given their $<100 \mathrm{~nm}$ nanoscale size, these EVs have become attractive nanostructures to treat a viral infection or their associated neuropathologies [137-139].

Potential treatments against viral infections are currently being investigated and range from vaccines to therapeutic drugs $[140,141]$. Antiviral agents must be carried across cellular barriers, such as the placental barrier (PB) or the BBB, to reach target cells [141]. The development of EVs as nanocarriers to transport therapeutic agents across the PB may provide a drug/gene delivery system capable of treating a ZIKV infection in-utero or delivering therapeutics across the BBB to treat a neurotropic virus infection of the CNS.

EVs are capable of transporting both hydrophobic and hydrophilic molecules. Hydrophilic compounds are stored in the interior, and hydrophobic agents embedded within the lipid membrane. However, unlike liposomes, exosomes are not optimized for the encapsulation of hydrophilic macromolecules [138]. Thus, liposomes can carry both hydrophobic and hydrophilic drugs and molecules to a target site, whereas exosomes will face challenges in the encapsulation of hydrophilic agents [138]. Additionally, the loading capacity of the exosomes is low due to the presence of proteins and nucleic acids already within [138]. To improve cell targeting, exosomes may be generated by cells expressing ligands with a 
high binding affinity to the target cells. However, for liposomes, using a functionalized polymer to coat the liposome, generating a nanobin that improves targeted drug delivery [138]. For neurotropic viruses, EVs could deliver therapeutics across the BBB, potentially reducing viral-associated neuropathology [124,142]. Inhibition of the ESCRT machinery is a promising option for HIV-1 therapeutics since HIV-1 appropriates ESCRT. TSG101 disruption via the small molecule inhibitor FGI-104 could prevent HIV-1 pathogenesis [143]. More research is needed to elucidate both the mechanism of action and potential side effects of FGI-104. Overall, given EV properties, EVs may serve as the next class of antiviral therapeutics, with fewer side effects and outstanding biocompatibility.

\section{Conclusions}

EVs play dichotomous roles in viral infections and pathology. In this review, we summarize clinically relevant viruses shown to interact with EVs and EV-mediated effects on viral infection and pathology, summarized in (Table 1). Not only are EVs critical for intracellular communication, but they may also represent a novel innate antiviral mechanism. Viruses exploit the EV biogenesis pathway to promote: viral infection, replication, spread, and pathology. Aside from promoting their pathology, viruses use EVs to modulate antiviral immune responses.

Table 1. Summary of EV-mediated effect in viral pathogenesis.

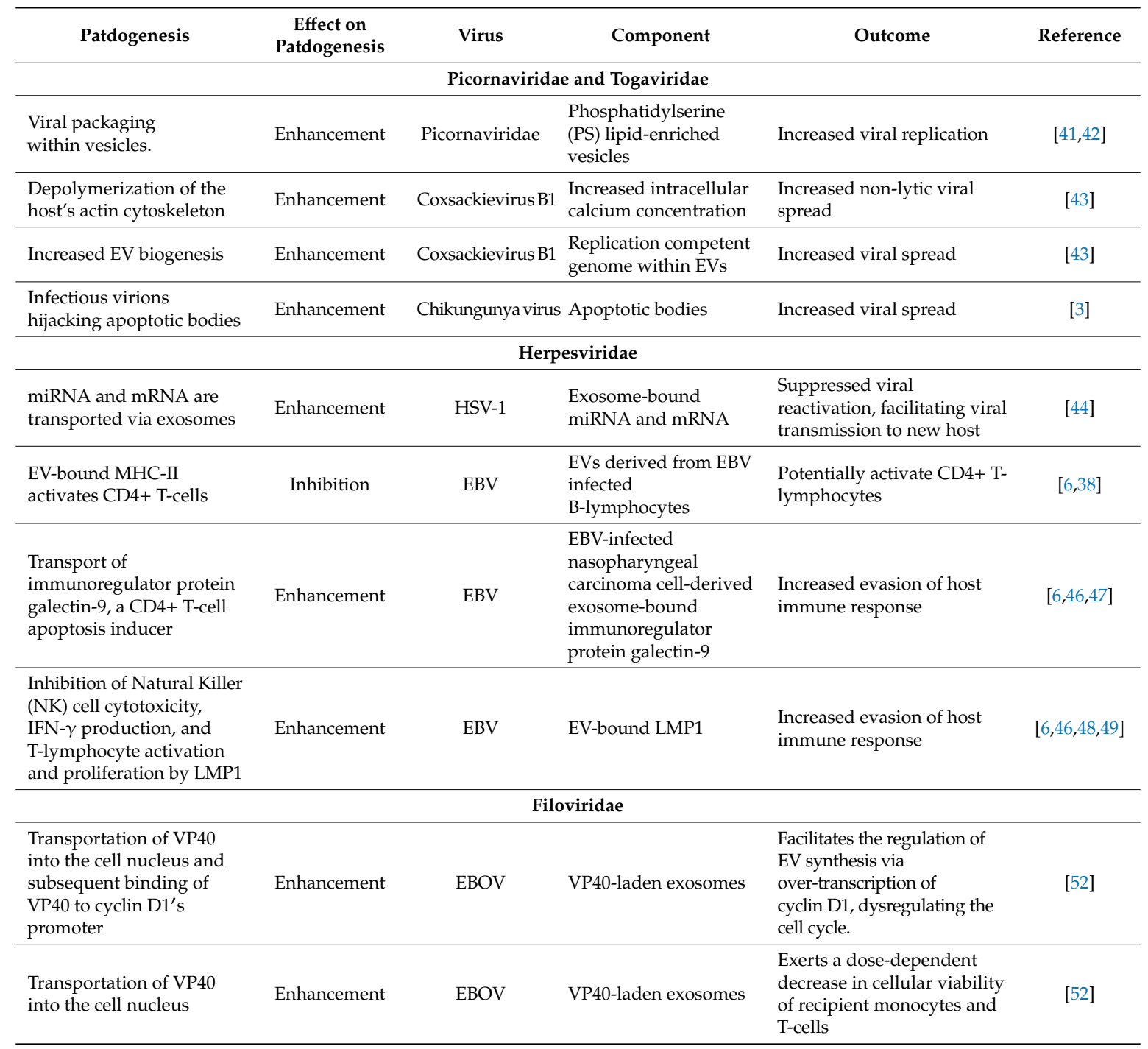


Table 1. Cont.




Table 1. Cont.

\begin{tabular}{|c|c|c|c|c|c|}
\hline Patdogenesis & $\begin{array}{c}\text { Effect on } \\
\text { Patdogenesis }\end{array}$ & Virus & Component & Outcome & Reference \\
\hline $\begin{array}{l}\text { HBV modulation of } \\
\text { exosome-bound proteins, } \\
\text { including the increase of } 5 \\
\text { proteasome subunit } \\
\text { proteins: PSMD1, PSMD7, } \\
\text { PSMD14, PSMC1, and } \\
\text { PSMC2, enhancing } \\
\text { proteolytic activity }\end{array}$ & Enhancement & HBV & $\begin{array}{l}35 \text { exosome-bound } \\
\text { proteins quantitatively } \\
\text { altered as a result of } \\
\text { HBV infection in } \\
\text { HBV-infected } \\
\text { HepAD38 } \\
\text { hepatoblastoma cell } \\
\text { line-derived exosomes }\end{array}$ & $\begin{array}{l}\text { Significant reducing } \\
\text { monocyte IL-6 production } \\
\text { and modulation of } \\
\text { proinflammatory molecules }\end{array}$ & [71] \\
\hline $\begin{array}{l}\text { Uptake of these } \\
\text { HBV-laden exosomes by } \\
\text { cells }\end{array}$ & Enhancement & HBV & HBV-laden exosomes & $\begin{array}{l}\text { Impairment of NK cell } \\
\text { production of IFN- } \gamma, \text { NK cell } \\
\text { survival and proliferation, } \\
\text { cytolytic activity, and NK } \\
\text { cell responsiveness to } \\
\text { stimulation from poly (I:C) }\end{array}$ & [72] \\
\hline \multicolumn{6}{|c|}{ Flaviviridae } \\
\hline $\begin{array}{l}\text { Viral packaging within } \\
\text { vesicles. }\end{array}$ & Enhancement & $\mathrm{HCV}$ & $\begin{array}{l}\text { Exosome-bound viral } \\
\text { particles }\end{array}$ & $\begin{array}{l}\text { Increased viral spread. } \\
\text { Activate immune cells and } \\
\text { establish infection }\end{array}$ & {$[74,75]$} \\
\hline $\begin{array}{l}\text { Transportation of viral } \\
\text { regulatory elements: } \\
\text { Human Ago } 2 \text { and miR-122 }\end{array}$ & Enhancement & $\mathrm{HCV}$ & $\begin{array}{l}\text { Exosome-bound Ago2 } \\
\text { and miR-122 }\end{array}$ & Increased viral spread & {$[74,76]$} \\
\hline $\begin{array}{l}\text { Downregulation of miR-21 } \\
\text { after exposure to EVs }\end{array}$ & Inhibition & ZIKV & $\begin{array}{l}\text { Infected HPT } \\
\text { cell-derived EVs }\end{array}$ & $\begin{array}{l}\text { Decreased TLR7-mediated } \\
\text { neurotoxicity }\end{array}$ & {$[87,88]$} \\
\hline $\begin{array}{l}\text { Exposure of placental cells } \\
\text { to EVs }\end{array}$ & Enhancement & ZIKV & $\begin{array}{l}\text { Macrophage-derived } \\
\text { exosomes }\end{array}$ & $\begin{array}{l}\text { Induction of placental } \\
\text { proinflammatory cytokine } \\
\text { production. }\end{array}$ & [91] \\
\hline $\begin{array}{l}\text { Stimulation of human } \\
\text { macrophage IL-1 } \beta \\
\text { secretion }\end{array}$ & Enhancement & ZIKV & $\begin{array}{l}\text { ZIKV NS5-mediated } \\
\text { activation of NLRP3 }\end{array}$ & $\begin{array}{l}\text { Activation of host } \\
\text { inflammatory response and } \\
\text { macrophage recruitment } \\
\text { promotes inflammation }\end{array}$ & [92] \\
\hline $\begin{array}{l}\text { EVs transmitted across } \\
\text { neurons }\end{array}$ & Enhancement & ZIKV & $\begin{array}{l}\text { EV-bound ZIKV-RNA } \\
\text { and E-protein }\end{array}$ & $\begin{array}{l}\text { Increased ZIKV } \\
\text { transmission across neurons }\end{array}$ & [93] \\
\hline $\begin{array}{l}\text { Modulation of SMPD3 } \\
\text { activity as a result of ZIKV } \\
\text { cortical neuron infection }\end{array}$ & Enhancement & ZIKV & EV-bound SMPD3 & $\begin{array}{l}\text { Increased EV biogenesis, } \\
\text { viral burden, and viral } \\
\text { transmission }\end{array}$ & [93] \\
\hline \multicolumn{6}{|c|}{ Retrovirdae } \\
\hline $\begin{array}{l}\text { Release of HIV-1 infected } \\
\text { cell-derived EVs }\end{array}$ & Enhancement & HIV & $\begin{array}{l}\text { gp120 laden HIV-1 } \\
\text { envelope (Env) protein }\end{array}$ & $\begin{array}{l}\text { Increased HIV-1 infectivity } \\
\text { in lymphoid tissues }\end{array}$ & [119-122] \\
\hline $\begin{array}{l}\text { Increased EV-mediated } \\
\text { Nef egress }\end{array}$ & Enhancement & HIV & EV-bound Nef protein & $\begin{array}{l}\text { Increased EV secretion, } \\
\text { presence of MVBs within } \\
\text { cells, decay of CD4+ T-cell } \\
\text { populations }\end{array}$ & [123-126] \\
\hline
\end{tabular}


Table 1. Cont.

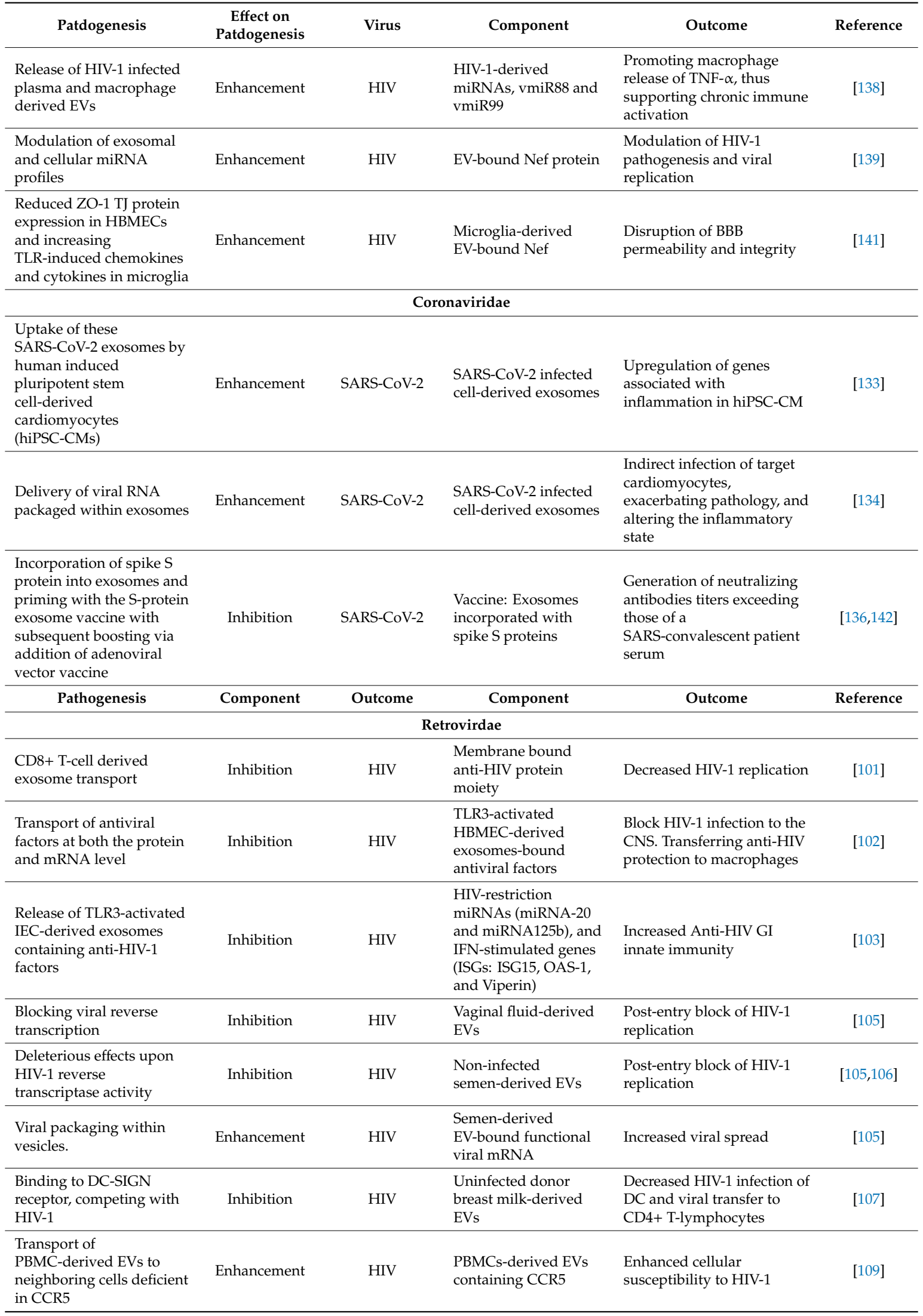


Table 1. Cont.

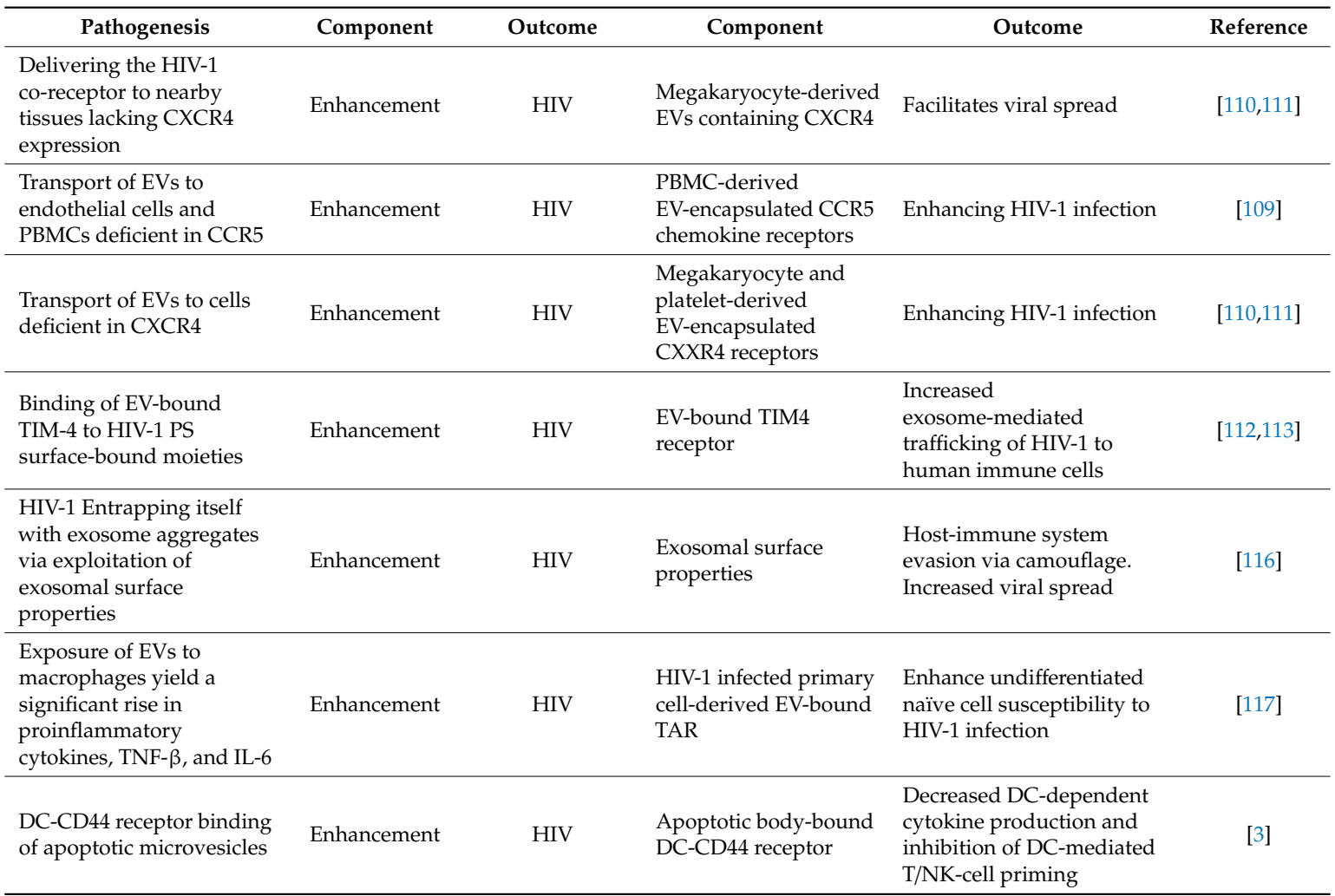

Author Contributions: Researched literature and/or contributed to the writing of the review: A.C. and A.D.R.; M.N. reviewed and edited article. All authors have read and agreed to the published version of the manuscript.

Funding: This work was supported by the FIU Herbert Wertheim pilot grant, Miami Center for AIDS research(CFAR) at University of Miami School of Medicine pilot grant; NIH R01DA044998.

Acknowledgments: The completion of this review would not have been possible, if not for the many researchers who have investigated the field of exosomes and their role in viral pathology.

Conflicts of Interest: The authors declare no conflict of interest.

\section{References}

1. Van Niel, G.; D'Angelo, G.; Raposo, G. Shedding light on the cell biology of extracellular vesicles. Nat. Rev. Mol. Cell Biol. 2018, 19, 213-228. [CrossRef] [PubMed]

2. Johnstone, R.M.; Adam, M.; Hammond, J.R.; Orr, L.; Turbide, C. Vesicle formation during reticulocyte maturation. Association of plasma membrane activities with released vesicles (exosomes). J. Biol. Chem. 1987, 262, 9412-9420. [PubMed]

3. Caruso, S.; Poon, I.K.H. Apoptotic Cell-Derived extracellular vesicles: More Than Just Debris. Front. Immunol. 2018, 9, 1486. [CrossRef] [PubMed]

4. Robbins, P.D.; Morelli, A.E. Regulation of immune responses by extracellular vesicles. Nat. Rev. Immunol. 2014, 14, 195-208. [CrossRef]

5. MacKenzie, A.; Wilson, H.L.; Kiss-Toth, E.; Dower, S.K.; North, R.A.; Surprenant, A. Rapid Secretion of Interleukin-1 $\beta$ by Microvesicle Shedding. Immunity 2001, 15, 825-835. [CrossRef]

6. Alenquer, M.; Amorim, M.J. Exosome Biogenesis, Regulation, and Function in Viral Infection. Viruses 2015, 7, 5066-5083. [CrossRef]

7. Camussi, G.; Deregibus, M.C.; Bruno, S.; Grange, C.; Fonsato, V.; Tetta, C. Exosome/microvesicle-mediated epigenetic reprogramming of cells. Am. J. Cancer Res. 2011, 1, 98-110.

8. Eitan, E.; Suire, C.; Zhang, S.; Mattson, M.P. Impact of lysosome status on extracellular vesicle content and release. Ageing Res. Rev. 2016, 32, 65-74. [CrossRef] 
9. Trajkovic, K.; Hsu, C.; Chiantia, S.; Rajendran, L.; Wenzel, D.; Wieland, F.; Schwille, P.; Brugger, B.; Simons, M. Ceramide triggers budding of exosome vesicles into multivesicular Endosomes. Science 2008, 319, 1244-1247. [CrossRef]

10. Menck, K.; Sonmezer, C.; Worst, T.S.; Schulz, M.; Dihazi, G.H.; Streit, F.; Erdmann, G.; Kling, S.; Boutros, M.; Binder, C.; et al. Neutral sphingomyelinases control extracellular vesicles budding from the plasma membrane. J. Extracell. Vesicles 2017, 6, 1378056. [CrossRef]

11. Andreu, Z.; Yanez-Mo, M. Tetraspanins in extracellular vesicle formation and function. Front. Immunol. 2014, 5, 442. [CrossRef] [PubMed]

12. Akers, J.C.; Gonda, D.; Kim, R.; Carter, B.S.; Chen, C.C. Biogenesis of extracellular vesicles (EV): Exosomes, microvesicles, retrovirus-like vesicles, and apoptotic bodies. J. Neurooncol. 2013, 113, 1-11. [CrossRef] [PubMed]

13. Kowal, J.; Tkach, M.; Thery, C. Biogenesis and secretion of exosomes. Curr. Opin. Cell Biol. 2014, $29,116-125$. [CrossRef] [PubMed]

14. Thery, C.; Boussac, M.; Veron, P.; Ricciardi-Castagnoli, P.; Raposo, G.; Garin, J.; Amigorena, S. Proteomic analysis of dendritic cell-derived exosomes: A secreted subcellular compartment distinct from apoptotic vesicles. J. Immunol. 2001, 166, 7309-7318. [CrossRef]

15. Hsu, C.; Morohashi, Y.; Yoshimura, S.; Manrique-Hoyos, N.; Jung, S.; Lauterbach, M.A.; Bakhti, M.; Gronborg, M.; Mobius, W.; Rhee, J.; et al. Regulation of exosome secretion by Rab35 and its GTPase-activating proteins TBC1D10A-C. J. Cell Biol. 2010, 189, 223-232. [CrossRef]

16. Savina, A.; Fader, C.M.; Damiani, M.T.; Colombo, M.I. Rab11 promotes docking and fusion of multivesicular bodies in a calcium-dependent manner. Traffic 2005, 6, 131-143. [CrossRef]

17. Ostrowski, M.; Carmo, N.B.; Krumeich, S.; Fanget, I.; Raposo, G.; Savina, A.; Moita, C.F.; Schauer, K.; Hume, A.N.; Freitas, R.P.; et al. Rab27a and Rab27b control different steps of the exosome secretion pathway. Nat. Cell Biol. 2010, 12, 19-30. [CrossRef]

18. Dias, M.V.S.; Costa, C.S.; daSilva, L.L.P. The Ambiguous Roles of Extracellular Vesicles in HIV Replication and Pathogenesis. Front. Microbiol. 2018, 9, 2411. [CrossRef]

19. Baixauli, F.; Lopez-Otin, C.; Mittelbrunn, M. Exosomes and autophagy: Coordinated mechanisms for the maintenance of cellular fitness. Front. Immunol. 2014, 5, 403. [CrossRef]

20. Bretz, N.P.; Ridinger, J.; Rupp, A.K.; Rimbach, K.; Keller, S.; Rupp, C.; Marme, F.; Umansky, L.; Umansky, V.; Eigenbrod, T; et al. Body fluid exosomes promote secretion of inflammatory cytokines in monocytic cells via Toll-like receptor signaling. J. Biol. Chem. 2013, 288, 36691-36702. [CrossRef]

21. Buzas, E.I.; Gyorgy, B.; Nagy, G.; Falus, A.; Gay, S. Emerging role of extracellular vesicles in inflammatory diseases. Nat. Rev. Rheumatol. 2014, 10, 356-364. [CrossRef] [PubMed]

22. Clayton, A.; Court, J.; Navabi, H.; Adams, M.; Mason, M.D.; Hobot, J.A.; Newman, G.R.; Jasani, B. Analysis of antigen presenting cell derived exosomes, based on immuno-magnetic isolation and flow cytometry. J. Immunol. Methods 2001, 247, 163-174. [CrossRef]

23. Kahlert, C.; Kalluri, R. Exosomes in tumor microenvironment influence cancer progression and metastasis. J. Mol. Med. 2013, 91, 431-437. [CrossRef]

24. Melo, S.A.; Sugimoto, H.; O'Connell, J.T.; Kato, N.; Villanueva, A.; Vidal, A.; Qiu, L.; Vitkin, E.; Perelman, L.T.; Melo, C.A.; et al. Cancer exosomes perform cell-independent microRNA biogenesis and promote tumorigenesis. Cancer Cell 2014, 26, 707-721. [CrossRef] [PubMed]

25. Raposo, G.; Nijman, H.W.; Stoorvogel, W.; Liejendekker, R.; Harding, C.V.; Melief, C.J.; Geuze, H.J. B lymphocytes secrete antigen-presenting vesicles. J. Exp. Med. 1996, 183, 1161-1172. [CrossRef]

26. Chahar, H.S.; Bao, X.Y.; Casola, A. Exosomes and Their Role in the Life Cycle and Pathogenesis of RNA Viruses. Viruses 2015, 7, 3204-3225. [CrossRef]

27. Ramakrishnaiah, V.; Thumann, C.; Fofana, I.; Habersetzer, F.; Pan, Q.W.; de Ruiter, P.E.; Willemsen, R.; Demmers, J.A.A.; Raj, V.S.; Jenster, G.; et al. Exosome-mediated transmission of hepatitis $\mathrm{C}$ virus between human hepatoma Huh7.5 cells. Proc. Natl. Acad. Sci. USA 2013, 110, 13109-13113. [CrossRef]

28. Altan-Bonnet, N. Extracellular vesicles are the Trojan horses of viral infection. Curr. Opin. Microbiol. 2016, 32, 77-81. [CrossRef]

29. Chen, Y.H.; Du, W.; Hagemeijer, M.C.; Takvorian, P.M.; Pau, C.; Cali, A.; Brantner, C.A.; Stempinski, E.S.; Connelly, P.S.; Ma, H.C.; et al. Phosphatidylserine vesicles enable efficient en bloc transmission of enteroviruses. Cell 2015, 160, 619-630. [CrossRef] 
30. Inal, J.M.; Jorfi, S. Coxsackievirus B transmission and possible new roles for extracellular vesicles. Biochem. Soc. Trans. 2013, 41, 299-302. [CrossRef]

31. Kalamvoki, M.; Du, T.; Roizman, B. Cells infected with herpes simplex virus 1 export to uninfected cells exosomes containing STING, viral mRNAs, and microRNAs. Proc. Natl. Acad. Sci. USA 2014, 111, E4991-E4996. [CrossRef] [PubMed]

32. Gutzeit, C.; Nagy, N.; Gentile, M.; Lyberg, K.; Gumz, J.; Vallhov, H.; Puga, I.; Klein, E.; Gabrielsson, S.; Cerutti, A.; et al. Exosomes derived from Burkitt's lymphoma cell lines induce proliferation, differentiation, and class-switch recombination in B cells. J. Immunol. 2014, 192, 5852-5862. [CrossRef] [PubMed]

33. Keryer-Bibens, C.; Pioche-Durieu, C.; Villemant, C.; Souquere, S.; Nishi, N.; Hirashima, M.; Middeldorp, J.; Busson, P. Exosomes released by EBV-infected nasopharyngeal carcinoma cells convey the viral latent membrane protein 1 and the immunomodulatory protein galectin 9. BMC Cancer 2006, 6, 283. [CrossRef] [PubMed]

34. Klibi, J.; Niki, T.; Riedel, A.; Pioche-Durieu, C.; Souquere, S.; Rubinstein, E.; Le Moulec, S.; Guigay, J.; Hirashima, M.; Guemira, F.; et al. Blood diffusion and Th1-suppressive effects of galectin-9-containing exosomes released by Epstein-Barr virus-infected nasopharyngeal carcinoma cells. Blood 2009, 113, 1957-1966. [CrossRef]

35. Dukers, D.F.; Meij, P.; Vervoort, M.B.; Vos, W.; Scheper, R.J.; Meijer, C.J.; Bloemena, E.; Middeldorp, J.M. Direct immunosuppressive effects of EBV-encoded latent membrane protein 1. J. Immunol. 2000, 165, 663-670. [CrossRef]

36. Flanagan, J.; Middeldorp, J.; Sculley, T. Localization of the Epstein-Barr virus protein LMP 1 to exosomes. J. Gen. Virol. 2003, 84, 1871-1879. [CrossRef]

37. Baseler, L.; Chertow, D.S.; Johnson, K.M.; Feldmann, H.; Morens, D.M. The Pathogenesis of Ebola Virus Disease. Ann. Rev. Pathol. Mech. Dis. 2017, 12, 387-418. [CrossRef]

38. Nehls, J.; Businger, R.; Hoffmann, M.; Brinkmann, C.; Fehrenbacher, B.; Schaller, M.; Maurer, B.; Schonfeld, C.; Kramer, D.; Hailfinger, S.; et al. Release of Immunomodulatory Ebola Virus Glycoprotein-Containing Microvesicles Is Suppressed by Tetherin in a Species-Specific Manner. Cell Rep. 2019, 26, 1841-1853.e6. [CrossRef]

39. Pleet, M.L.; Erickson, J.; DeMarino, C.; Barclay, R.A.; Cowen, M.; Lepene, B.; Liang, J.; Kuhn, J.H.; Prugar, L.; Stonier, S.W.; et al. Ebola Virus VP40 Modulates Cell Cycle and Biogenesis of Extracellular Vesicles. J. Infect. Dis. 2018, 218, S365-S387. [CrossRef]

40. Messaoudi, I.; Amarasinghe, G.K.; Basler, C.F. Filovirus pathogenesis and immune evasion: Insights from Ebola virus and Marburg virus. Nat. Rev. Microbiol. 2015, 13, 663-676. [CrossRef]

41. Pleet, M.L.; Mathiesen, A.; DeMarino, C.; Akpamagbo, Y.A.; Barclay, R.A.; Schwab, A.; Iordanskiy, S.; Sampey, G.C.; Lepene, B.; Ilinykh, P.A.; et al. Ebola VP40 in Exosomes Can Cause Immune Cell Dysfunction (vol 7, 1765, 2016). Front. Microbiol. 2018, 9, 692. [CrossRef] [PubMed]

42. Chahar, H.S.; Corsello, T.; Kudlicki, A.S.; Komaravelli, N.; Casola, A. Respiratory Syncytial Virus Infection Changes Cargo Composition of Exosome Released from Airway Epithelial Cells. Sci. Rep. 2018, 8, 387. [CrossRef] [PubMed]

43. Bomberger, J.; Lashua, L.; Fischer, D.; Hendricks, M. Exosome-Associated Iron Release during Respiratory Virus Co-Infection Enhances Pseudomonas aeruginosa Biofilm Growth. FASEB J. 2016, 30, 1223. [CrossRef]

44. Kesimer, M.; Scull, M.; Brighton, B.; DeMaria, G.; Burns, K.; O’Neal, W.; Pickles, R.J.; Sheehan, J.K. Characterization of exosome-like vesicles released from human tracheobronchial ciliated epithelium: A possible role in innate defense. FASEB J. 2009, 23, 1858-1868. [CrossRef]

45. Nadmdari, H.; Keshavarz, M.; Mokhtari-Azad, T.; Rezaei, F. Evaluation of Antibody and Cytokines Responses in Intranasally and Intramuscularly Administrated BALB/C Mice with Influenza Virus-Like Particle. Acta Med. Iran. 2017, 55, 604-611. [PubMed]

46. Deriu, E.; Boxx, G.M.; He, X.; Pan, C.; Benavidez, S.D.; Cen, L.; Rozengurt, N.; Shi, W.; Cheng, G. Influenza Virus Affects Intestinal Microbiota and Secondary Salmonella Infection in the Gut through Type I Interferons. PLoS Pathog. 2016, 12, e1005572. [CrossRef]

47. Cheng, L.; Sharples, R.A.; Scicluna, B.J.; Hill, A.F. Exosomes provide a protective and enriched source of miRNA for biomarker profiling compared to intracellular and cell-free blood. J. Extracell. Vesicles 2014, 3. [CrossRef] 
48. Keshavarz, M.; Dianat-Moghadam, H.; Sofiani, V.H.; Karimzadeh, M.; Zargar, M.; Moghoofei, M.; Biglari, H.; Ghorbani, S.; Nahand, J.S.; Mirzaei, H. miRNA-based strategy for modulation of influenza A virus infection. Epigenomics 2018, 10, 829-844. [CrossRef]

49. Loveday, E.-K.; Svinti, V.; Diederich, S.; Pasick, J.; Jean, F. Temporal- and strain-specific host microRNA molecular signatures associated with swine-origin H1N1 and avian-origin H7N7 influenza A virus infection. J. Virol. 2012, 86, 6109-6122. [CrossRef]

50. Tambyah, P.A.; Sepramaniam, S.; Mohamed Ali, J.; Chai, S.C.; Swaminathan, P.; Armugam, A.; Jeyaseelan, K. microRNAs in circulation are altered in response to influenza A virus infection in humans. PLoS ONE 2013, 8, e76811. [CrossRef] [PubMed]

51. Liu, Y.M.; Tseng, C.H.; Chen, Y.C.; Yu, W.Y.; Ho, M.Y.; Ho, C.Y.; Lai, M.M.C.; Su, W.C. Exosome-delivered and Y RNA-derived small RNA suppresses influenza virus replication. J. Biomed. Sci. 2019, 26, 58. [CrossRef]

52. Cypryk, W.; Lorey, M.; Puustinen, A.; Nyman, T.A.; Matikainen, S. Proteomic and Bioinformatic Characterization of Extracellular Vesicles Released from Human Macrophages upon Influenza A Virus Infection. J. Proteome Res. 2017, 16, 217-227. [CrossRef]

53. Bruce, E.A.; Digard, P.; Stuart, A.D. The Rab11 pathway is required for influenza a virus budding and filament formation. J. Virol. 2010, 84, 5848-5859. [CrossRef]

54. Hutchinson, E.C.; Charles, P.D.; Hester, S.S.; Thomas, B.; Trudgian, D.; Martínez-Alonso, M.; Fodor, E. Conserved and host-specific features of influenza virion architecture. Nat. Commun. 2014, 5, 4816. [CrossRef]

55. Kapoor, N.R.; Chadha, R.; Kumar, S.; Choedon, T.; Reddy, V.S.; Kumar, V. The HBx gene of hepatitis B virus can influence hepatic microenvironment via exosomes by transferring its mRNA and protein. Virus Res. 2017, 240, 166-174. [CrossRef]

56. Kouwaki, T.; Fukushima, Y.; Daito, T.; Sanada, T.; Yamamoto, N.; Mifsud, E.J.; Leong, C.R.; Tsukiyama-Kohara, K.; Kohara, M.; Matsumoto, M.; et al. Extracellular Vesicles Including Exosomes Regulate Innate Immune Responses to Hepatitis B Virus Infection. Front. Immunol. 2016, 7, 335. [CrossRef]

57. Spear, P.; Wu, M.-R.; Sentman, M.-L.; Sentman, C.L. NKG2D ligands as therapeutic targets. Cancer Immun. 2013, 13,8 .

58. Jia, X.; Chen, J.; Megger, D.A.; Zhang, X.; Kozlowski, M.; Zhang, L.; Fang, Z.; Li, J.; Chu, Q.; Wu, M.; et al. Label-free Proteomic Analysis of Exosomes Derived from Inducible Hepatitis B Virus-Replicating HepAD38 Cell Line. Mol. Cell. Proteom. 2017, 16, S144-S160. [CrossRef]

59. Yang, Y.; Han, Q.; Hou, Z.; Zhang, C.; Tian, Z.; Zhang, J. Exosomes mediate hepatitis B virus (HBV) transmission and NK-cell dysfunction. Cell. Mol. Immunol. 2017, 14, 465-475. [CrossRef]

60. Yao, Z.; Qiao, Y.; Li, X.; Chen, J.; Ding, J.; Bai, L.; Shen, F.; Shi, B.; Liu, J.; Peng, L.; et al. Exosomes Exploit the Virus Entry Machinery and Pathway to Transmit Alpha Interferon-Induced Antiviral Activity. J. Virol. 2018, 92, e01578-18. [CrossRef]

61. Bukong, T.N.; Momen-Heravi, F.; Kodys, K.; Bala, S.; Szabo, G. Exosomes from Hepatitis C Infected Patients Transmit HCV Infection and Contain Replication Competent Viral RNA in Complex with Ago2-miR122-HSP90. PLoS Pathog. 2014, 10, e1004424. [CrossRef]

62. Cosset, F.L.; Dreux, M. HCV transmission by hepatic exosomes establishes a productive infection. J. Hepatol. 2014, 60, 674-675. [CrossRef] [PubMed]

63. Wilson, J.A.; Zhang, C.; Huys, A.; Richardson, C.D. Human Ago2 Is Required for Efficient MicroRNA 122 Regulation of Hepatitis C Virus RNA Accumulation and Translation. J. Virol. 2011, 85, 2342-2350. [CrossRef] [PubMed]

64. Zhou, W.S.; Woodson, M.; Neupane, B.; Bai, F.W.; Sherman, M.B.; Choi, K.H.; Neelakanta, G.; Sultana, H. Exosomes serve as novel modes of tick-borne flavivirus transmission from arthropod to human cells and facilitates dissemination of viral RNA and proteins to the vertebrate neuronal cells. PLoS Pathog. 2018, 14, e1006764. [CrossRef]

65. Anderson, M.R.; Kashanchi, F.; Jacobson, S. Exosomes in Viral Disease. Neurotherapeutics 2016, 13, 535-546. [CrossRef] [PubMed]

66. Zhang, Z.W.; Li, Z.L.; Yuan, S. The Role of Secretory Autophagy in Zika Virus Transfer through the Placental Barrier. Front. Cell. Infect. Microbiol. 2017, 6, 206. [CrossRef] [PubMed]

67. Wang, L.; Valderramos, S.G.; Wu, A.; Ouyang, S.; Li, C.; Brasil, P.; Bonaldo, M.; Coates, T.; Nielsen-Saines, K.; Jiang, T.; et al. From Mosquitos to Humans: Genetic Evolution of Zika Virus. Cell Host Microbe 2016, 19, 561-565. [CrossRef] [PubMed] 
68. Klase, Z.A.; Khakhina, S.; Schneider Ade, B.; Callahan, M.V.; Glasspool-Malone, J.; Malone, R. Zika Fetal Neuropathogenesis: Etiology of a Viral Syndrome. PLoS Negl. Trop. Dis. 2016, 10, e0004877. [CrossRef] [PubMed]

69. Bayer, A.; Lennemann, N.J.; Ouyang, Y.; Bramley, J.C.; Morosky, S.; Marques, E.T., Jr.; Cherry, S.; Sadovsky, Y.; Coyne, C.B. Type III Interferons Produced by Human Placental Trophoblasts Confer Protection against Zika Virus Infection. Cell Host Microbe 2016, 19, 705-712. [CrossRef] [PubMed]

70. Chiramel, A.I.; Best, S.M. Role of autophagy in Zika virus infection and pathogenesis. Virus Res. 2018, 254, 34-40. [CrossRef]

71. Delorme-Axford, E.; Donker, R.B.; Mouillet, J.F.; Chu, T.; Bayer, A.; Ouyang, Y.; Wang, T.; Stolz, D.B.; Sarkar, S.N.; Morelli, A.E.; et al. Human placental trophoblasts confer viral resistance to recipient cells. Proc. Natl. Acad. Sci. USA 2013, 110, 12048-12053. [CrossRef]

72. Bayer, A.; Lennemann, N.J.; Ouyang, Y.; Sadovsky, E.; Sheridan, M.A.; Roberts, R.M.; Coyne, C.B.; Sadovsky, Y. Chromosome 19 microRNAs exert antiviral activity independent from type III interferon signaling. Placenta 2018, 61, 33-38. [CrossRef] [PubMed]

73. Huang, Y.L.; Li, Y.J.; Zhang, H.N.; Zhao, R.Z.; Jing, R.; Xu, Y.H.; He, M.; Peer, J.; Kim, Y.C.; Luo, J.T.; et al. Zika virus propagation and release in human fetal astrocytes can be suppressed by neutral sphingomyelinase-2 inhibitor GW4869. Cell Discov. 2018, 4, 19. [CrossRef] [PubMed]

74. Aagaard, K.M.; Lahon, A.; Suter, M.A.; Arya, R.P.; Seferovic, M.D.; Vogt, M.B.; Hu, M.; Stossi, F.; Mancini, M.A.; Harris, R.A.; et al. Primary Human Placental Trophoblasts are Permissive for Zika Virus (ZIKV) Replication. Sci. Rep. 2017, 7, 41389. [CrossRef]

75. Yelamanchili, S.V.; Lamberty, B.G.; Rennard, D.A.; Morsey, B.M.; Hochfelder, C.G.; Meays, B.M.; Levy, E.; Fox, H.S. MiR-21 in Extracellular Vesicles Leads to Neurotoxicity via TLR7 Signaling in SIV Neurological Disease. PLoS Pathog. 2015, 11, e1005032. [CrossRef]

76. Muller, J.A.; Harms, M.; Kruger, F.; Gross, R.; Joas, S.; Hayn, M.; Dietz, A.N.; Lippold, S.; von Einem, J.; Schubert, A.; et al. Semen inhibits Zika virus infection of cells and tissues from the anogenital region. Nat. Commun. 2018, 9, 2207. [CrossRef]

77. Ngono, A.E.; Shresta, S. Immune Response to Dengue and Zika. Annu. Rev. Immunol. 2018, 36, $279-308$. [CrossRef]

78. Holder, B.; Jones, T.; Sancho Shimizu, V.; Rice, T.F.; Donaldson, B.; Bouqueau, M.; Forbes, K.; Kampmann, B. Macrophage Exosomes Induce Placental Inflammatory Cytokines: A Novel Mode of Maternal-Placental Messaging. Traffic 2016, 17, 168-178. [CrossRef]

79. Wang, W.B.; Li, G.; Wu, D.; Luo, Z.; Pan, P.; Tian, M.F.; Wang, Y.C.; Xiao, F.; Li, A.X.; Wu, K.L.; et al. Zika virus infection induces host inflammatory responses by facilitating NLRP3 inflammasome assembly and interleukin-1 beta secretion. Nat. Commun. 2018, 9, 106. [CrossRef]

80. Zhou, W.S.; Woodson, M.; Sherman, M.B.; Neelakanta, G.; Sultana, H. Exosomes mediate Zika virus transmission through SMPD3 neutral Sphingomyelinase in cortical neurons. Emerg. Microbes Infect. 2019, 8, 307-326. [CrossRef]

81. Chun, T.W.; Fauci, A.S. HIV reservoirs: Pathogenesis and obstacles to viral eradication and cure. AIDS 2012, 26, 1261-1268. [CrossRef] [PubMed]

82. Deeks, S.G.; Overbaugh, J.; Phillips, A.; Buchbinder, S. HIV infection. Nat. Rev. Dis. Primers 2015, 1, 15035. [CrossRef] [PubMed]

83. Madison, M.N.; Okeoma, C.M. Exosomes: Implications in HIV-1 Pathogenesis. Viruses 2015, 7, $4093-4118$. [CrossRef] [PubMed]

84. Ebrahimi, D.; Richards, C.M.; Carpenter, M.A.; Wang, J.; Ikeda, T.; Becker, J.T.; Cheng, A.Z.; McCann, J.L.; Shaban, N.M.; Salamango, D.J.; et al. Genetic and mechanistic basis for APOBEC3H alternative splicing, retrovirus restriction, and counteraction by HIV-1 protease. Nat. Commun. 2018, 9, 4137. [CrossRef]

85. Miyagi, E.; Opi, S.; Takeuchi, H.; Khan, M.; Goila-Gaur, R.; Kao, S.; Strebel, K. Enzymatically active APOBEC3G is required for efficient inhibition of human immunodeficiency virus type 1. J. Virol. 2007, 81, 13346-13353. [CrossRef]

86. Holmes, M.; Zhang, F.W.; Bieniasz, P.D. Single-Cell and Single-Cycle Analysis of HIV-1 Replication. PLoS Pathog. 2015, 11, e1004961. [CrossRef] 
87. de Carvalho, J.V.; de Castro, R.O.; da Silva, E.Z.; Silveira, P.P.; da Silva-Januario, M.E.; Arruda, E.; Jamur, M.C.; Oliver, C.; Aguiar, R.S.; daSilva, L.L. Nef neutralizes the ability of exosomes from CD4+ T cells to act as decoys during HIV-1 infection. PLoS ONE 2014, 9, e113691. [CrossRef]

88. Tumne, A.; Prasad, V.S.; Chen, Y.; Stolz, D.B.; Saha, K.; Ratner, D.M.; Ding, M.; Watkins, S.C.; Gupta, P. Noncytotoxic suppression of human immunodeficiency virus type 1 transcription by exosomes secreted from CD8+ T cells. J. Virol. 2009, 83, 4354-4364. [CrossRef]

89. Sun, L.; Wang, X.; Zhou, Y.; Zhou, R.H.; Ho, W.Z.; Li, J.L. Exosomes contribute to the transmission of anti-HIV activity from TLR3-activated brain microvascular endothelial cells to macrophages. Antivir. Res. 2016, 134, 167-171. [CrossRef]

90. Guo, L.; Xu, X.Q.; Zhou, L.; Zhou, R.H.; Wang, X.; Li, J.L.; Liu, J.B.; Liu, H.; Zhang, B.; Ho, W.Z. Human Intestinal Epithelial Cells Release Antiviral Factors That Inhibit HIV Infection of Macrophages. Front. Immunol. 2018, 9, 247. [CrossRef]

91. Smith, J.A.; Daniel, R. Human vaginal fluid contains exosomes that have an inhibitory effect on an early step of the HIV-1 life cycle. AIDS 2016, 30, 2611-2616. [CrossRef] [PubMed]

92. Madison, M.N.; Jones, P.H.; Okeoma, C.M. Exosomes in human semen restrict HIV-1 transmission by vaginal cells and block intravaginal replication of LP-BM5 murine AIDS virus complex. Virology 2015, 482, 189-201. [CrossRef] [PubMed]

93. Madison, M.N.; Roller, R.J.; Okeoma, C.M. Human semen contains exosomes with potent anti-HIV-1 activity. Retrovirology 2014, 11, 102. [CrossRef] [PubMed]

94. Naslund, T.I.; Paquin-Proulx, D.; Paredes, P.T.; Vallhov, H.; Sandberg, J.K.; Gabrielsson, S. Exosomes from breast milk inhibit HIV-1 infection of dendritic cells and subsequent viral transfer to CD4+ T cells. AIDS 2014, 28, 171-180. [CrossRef] [PubMed]

95. Admyre, C.; Johansson, S.M.; Qazi, K.R.; Filen, J.J.; Lahesmaa, R.; Norman, M.; Neve, E.P.; Scheynius, A.; Gabrielsson, S. Exosomes with immune modulatory features are present in human breast milk. J. Immunol. 2007, 179, 1969-1978. [CrossRef]

96. Mack, M.; Kleinschmidt, A.; Bruhl, H.; Klier, C.; Nelson, P.J.; Cihak, J.; Plachy, J.; Stangassinger, M.; Erfle, V.; Schlondorff, D. Transfer of the chemokine receptor CCR5 between cells by membrane-derived microparticles: A mechanism for cellular human immunodeficiency virus 1 infection. Nat. Med. 2000, 6, 769-775. [CrossRef]

97. Rozmyslowicz, T.; Majka, M.; Kijowski, J.; Murphy, S.L.; Conover, D.O.; Poncz, M.; Ratajczak, J.; Gaulton, G.N.; Ratajczak, M.Z. Platelet- and megakaryocyte-derived microparticles transfer CXCR4 receptor to CXCR4-null cells and make them susceptible to infection by X4-HIV. AIDS 2003, 17, 33-42. [CrossRef]

98. Flaumenhaft, R.; Mairuhu, A.T.; Italiano, J.E. Platelet- and megakaryocyte-derived microparticles. Semin. Thromb. Hemost. 2010, 36, 881-887. [CrossRef]

99. Sims, B.; Farrow, A.L.; Williams, S.D.; Bansal, A.; Krendelchtchikov, A.; Matthews, Q.L. Tetraspanin blockage reduces exosome-mediated HIV-1 entry. Arch. Virol. 2018, 163, 1683-1689. [CrossRef]

100. Sims, B.; Farrow, A.L.; Williams, S.D.; Bansal, A.; Krendelchtchikov, A.; Gu, L.; Matthews, Q.L. Role of TIM-4 in exosome-dependent entry of HIV-1 into human immune cells. Int. J. Nanomed. 2017, 12, 4823-4833. [CrossRef]

101. Feng, D.; Zhao, W.L.; Ye, Y.Y.; Bai, X.C.; Liu, R.Q.; Chang, L.F.; Zhou, Q.; Sui, S.F. Cellular internalization of exosomes occurs through phagocytosis. Traffic 2010, 11, 675-687. [CrossRef] [PubMed]

102. Miyanishi, M.; Tada, K.; Koike, M.; Uchiyama, Y.; Kitamura, T.; Nagata, S. Identification of Tim4 as a phosphatidylserine receptor. Nature 2007, 450, 435-439. [CrossRef]

103. Kadiu, I.; Narayanasamy, P.; Dash, P.K.; Zhang, W.; Gendelman, H.E. Biochemical and biologic characterization of exosomes and microvesicles as facilitators of HIV-1 infection in macrophages. J. Immunol. 2012, 189, 744-754. [CrossRef] [PubMed]

104. Sampey, G.C.; Saifuddin, M.; Schwab, A.; Barclay, R.; Punya, S.; Chung, M.C.; Hakami, R.M.; Zadeh, M.A.; Lepene, B.; Klase, Z.A.; et al. Exosomes from HIV-1-infected Cells Stimulate Production of Pro-inflammatory Cytokines through Trans-activating Response (TAR) RNA. J. Biol. Chem. 2016, 291, 1251-1266. [CrossRef] [PubMed]

105. Birge, R.B.; Boeltz, S.; Kumar, S.; Carlson, J.; Wanderley, J.; Calianese, D.; Barcinski, M.; Brekken, R.A.; Huang, X.; Hutchins, J.T.; et al. Phosphatidylserine is a global immunosuppressive signal in efferocytosis, infectious disease, and cancer. Cell Death Differ. 2016, 23, 962-978. [CrossRef] [PubMed] 
106. Arakelyan, A.; Fitzgerald, W.; Zicari, S.; Vanpouille, C.; Margolis, L. Extracellular Vesicles Carry HIV Env and Facilitate Hiv Infection of Human Lymphoid Tissue. Sci. Rep. 2017, 7, 1695. [CrossRef] [PubMed]

107. Booth, A.M.; Fang, Y.; Fallon, J.K.; Yang, J.M.; Hildreth, J.E.; Gould, S.J. Exosomes and HIV Gag bud from endosome-like domains of the T cell plasma membrane. J. Cell Biol. 2006, 172, 923-935. [CrossRef] [PubMed]

108. Cabezas, S.C.; Federico, M. Sequences within RNA coding for HIV-1 Gag p17 are efficiently targeted to exosomes. Cell. Microbiol. 2013, 15, 412-429. [CrossRef] [PubMed]

109. Fang, Y.; Wu, N.; Gan, X.; Yan, W.; Morrell, J.C.; Gould, S.J. Higher-order oligomerization targets plasma membrane proteins and HIV gag to exosomes. PLoS Biol. 2007, 5, e158. [CrossRef]

110. Raymond, A.D.; Campbell-Sims, T.C.; Khan, M.; Lang, M.; Huang, M.B.; Bond, V.C.; Powell, M.D. HIV Type 1 Nef Is Released from Infected Cells in CD45(+) Microvesicles and Is Present in the Plasma of HIV-Infected Individuals. AIDS Res. Hum. Retrovir. 2011, 27, 167-178. [CrossRef]

111. Campbell, T.D.; Khan, M.; Huang, M.B.; Bond, V.C.; Powell, M.D. HIV-1 Nef protein is secreted into vesicles that can fuse with target cells and virions. Ethn. Dis. 2008, 18, S2-14-19.

112. Lenassi, M.; Cagney, G.; Liao, M.F.; Vaupotic, T.; Bartholomeeusen, K.; Cheng, Y.F.; Krogan, N.J.; Plemenitas, A.; Peterlin, B.M. HIV Nef is Secreted in Exosomes and Triggers Apoptosis in Bystander CD4(+) T Cells. Traffic 2010, 11, 110-122. [CrossRef]

113. Stumptner-Cuvelette, P.; Jouve, M.; Helft, J.; Dugast, M.; Glouzman, A.S.; Jooss, K.; Raposo, G.; Benaroch, P. Human immunodeficiency virus-1 Nef expression induces intracellular accumulation of multivesicular bodies and major histocompatibility complex class II complexes: Potential role of phosphatidylinositol 3-kinase. Mol. Biol. Cell 2003, 14, 4857-4870. [CrossRef] [PubMed]

114. Sevilya, Z.; Chorin, E.; Gal-Garber, O.; Zelinger, E.; Turner, D.; Avidor, B.; Berke, G.; Hassin, D. Killing of Latently HIV-Infected CD4 T Cells by Autologous CD8 T Cells Is Modulated by Nef. Front. Immunol. 2018, 9, 2068. [CrossRef]

115. Jacob, R.A.; Johnson, A.L.; Pawlak, E.N.; Dirk, B.S.; Van Nynatten, L.R.; Haeryfar, S.M.M.; Dikeakos, J.D. The interaction between HIV-1 Nef and adaptor protein-2 reduces Nefmediated CD4+ T cell apoptosis. Virology 2017, 509, 1-10. [CrossRef] [PubMed]

116. James, C.O.; Huang, M.B.; Khan, M.; Garcia-Barrio, M.; Powell, M.D.; Bond, V.C. Extracellular Nef protein targets CD4+ T cells for apoptosis by interacting with CXCR4 surface receptors. J. Virol. 2004, 78, 3099-3109. [CrossRef] [PubMed]

117. Lee, J.H.; Schierer, S.; Blume, K.; Dindorf, J.; Wittki, S.; Xiang, W.; Ostalecki, C.; Koliha, N.; Wild, S.; Schuler, G.; et al. HIV-Nef and ADAM17-Containing Plasma Extracellular Vesicles Induce and Correlate with Immune Pathogenesis in Chronic HIV Infection. Ebiomedicine 2016, 6, 103-113. [CrossRef]

118. Arenaccio, C.; Chiozzini, C.; Columba-Cabezas, S.; Manfredi, F.; Affabris, E.; Baur, A.; Federico, M. Exosomes from Human Immunodeficiency Virus Type 1 (HIV-1)-Infected Cells License Quiescent CD4(+) T Lymphocytes to Replicate HIV-1 through a Nef- and ADAM17-Dependent Mechanism. J. Virol. 2014, 88, 11529-11539. [CrossRef]

119. Roth, W.W.; Huang, M.B.; Addae Konadu, K.; Powell, M.D.; Bond, V.C. Micro RNA in Exosomes from HIV-Infected Macrophages. Int. J. Environ. Res. Public Health 2015, 13, 32. [CrossRef] [PubMed]

120. De Vries, W.; Berkhout, B. RNAi suppressors encoded by pathogenic human viruses. Int. J. Biochem. Cell Biol. 2008, 40, 2007-2012. [CrossRef]

121. Bernard, M.A.; Zhao, H.; Yue, S.C.; Anandaiah, A.; Koziel, H.; Tachado, S.D. Novel HIV-1 MiRNAs Stimulate TNF alpha Release in Human Macrophages via TLR8 Signaling Pathway. PLoS ONE 2014, 9, e106006. [CrossRef] [PubMed]

122. Aqil, M.; Naqvi, A.R.; Mallik, S.; Bandyopadhyay, S.; Maulik, U.; Jameel, S. The HIV Nef protein modulates cellular and exosomal miRNA profiles in human monocytic cells. J. Extracell. Vesicles 2014, 3. [CrossRef]

123. Boisse, L.; Gill, M.J.; Power, C. HIV infection of the central nervous system: Clinical features and neuropathogenesis. Neurol. Clin. 2008, 26, 799-819. [CrossRef] [PubMed]

124. Raymond, A.D.; Diaz, P.; Chevelon, S.; Agudelo, M.; Yndart-Arias, A.; Ding, H.; Kaushik, A.; Jayant, R.D.; Nikkhah-Moshaie, R.; Roy, U.; et al. Microglia-derived HIV Nef plus exosome impairment of the blood-brain barrier is treatable by nanomedicine-based delivery of Nef peptides. J. Neurovirol. 2016, 22, 129-139. [CrossRef] [PubMed]

125. Kuate, S.; Cinatl, J.; Doerr, H.W.; Überla, K. Exosomal vaccines containing the S protein of the SARS coronavirus induce high levels of neutralizing antibodies. Virology 2007, 362, 26-37. [CrossRef] [PubMed] 
126. Lai, M.M. Coronavirus: Organization, replication and expression of genome. Annu. Rev. Microbiol. 1990, 44, 303-333. [CrossRef]

127. Spaan, W.; Cavanagh, D.; Horzinek, M.C. Coronaviruses: Structure and Genome Expression. J. Gen. Virol. 1988, 69, 2939-2952. [CrossRef]

128. Kwon, Y.; Nukala, S.B.; Srivastava, S.; Miyamoto, H.; Ismail, N.I.; Ong, S.-B.; Lee, W.H.; Ong, S.-G. Exosomes Facilitate Transmission of SARS-CoV-2 Genome into Human Induced Pluripotent Stem Cell-Derived Cardiomyocytes. bioRxiv 2020. [CrossRef]

129. Giannessi, F.; Aiello, A.; Franchi, F.; Percario, Z.A.; Affabris, E. The Role of Extracellular Vesicles as Allies of HIV, HCV and SARS Viruses. Viruses 2020, 12, 571. [CrossRef]

130. Kang, J.-S. Chapter 20-The potential of exosomes as theragnostics in various clinical situations. In Exosomes; Edelstein, L., Smythies, J., Quesenberry, P., Noble, D., Eds.; Academic Press: Cambridge, MA, USA, 2020; pp. 467-486. [CrossRef]

131. Sengupta, V.; Sengupta, S.; Lazo, A.; Woods, P.; Nolan, A.; Bremer, N. Exosomes Derived from Bone Marrow Mesenchymal Stem Cells as Treatment for Severe COVID-19. Stem Cells Dev. 2020, 29, 747-754. [CrossRef]

132. Viscidi, R.P.; Shah, K.V. Chapter 157-Polyomaviruses. In Infectious Diseases, 3rd ed.; Cohen, J., Opal, S.M., Powderly, W.G., Eds.; Content Repository Only: London, UK, 2010; pp. 1570-1572.

133. Morris-Love, J.; Gee, G.V.; O’Hara, B.A.; Assetta, B.; Atkinson, A.L.; Dugan, A.S.; Haley, S.A.; Atwood, W.J. JC Polyomavirus Uses Extracellular Vesicles to Infect Target Cells. mBio 2019, 10. [CrossRef]

134. O’Hara, B.A.; Morris-Love, J.; Gee, G.V.; Haley, S.A.; Atwood, W.J. JC Virus infected choroid plexus epithelial cells produce extracellular vesicles that infect glial cells independently of the virus attachment receptor. PLoS Pathog. 2020, 16, e1008371. [CrossRef] [PubMed]

135. Giovannelli, I.; Clausi, V.; Nukuzuma, S.; Della Malva, N.; Nosi, D.; Giannecchini, S. Polyomavirus JC microRNA expression after infection in vitro. Virus Res. 2016, 213, 269-273. [CrossRef] [PubMed]

136. Handala, L.; Blanchard, E.; Raynal, P.I.; Roingeard, P.; Morel, V.; Descamps, V.; Castelain, S.; Francois, C.; Duverlie, G.; Brochot, E.; et al. BK Polyomavirus Hijacks Extracellular Vesicles for En Bloc Transmission. J. Virol. 2020, 94. [CrossRef] [PubMed]

137. Paliwal, R.; Babu, R.J.; Palakurthi, S. Nanomedicine scale-up technologies: Feasibilities and challenges. AAPS PharmSciTech 2014, 15, 1527-1534. [CrossRef] [PubMed]

138. McMillan, J.; Batrakova, E.; Gendelman, H.E. Cell delivery of therapeutic nanoparticles. Prog. Mol. Biol. Transl. Sci. 2011, 104, 563-601. [CrossRef] [PubMed]

139. Agrahari, V.; Agrahari, V.; Mitra, A.K. Nanocarrier fabrication and macromolecule drug delivery: Challenges and opportunities. Ther. Deliv. 2016, 7, 257-278. [CrossRef] [PubMed]

140. Wahid, B.; Ali, A.; Rafique, S.; Idrees, M. Current status of therapeutic and vaccine approaches against Zika virus. Eur. J. Intern. Med. 2017, 44, 12-18. [CrossRef] [PubMed]

141. Griffiths, S.K.; Campbell, J.P. Placental structure, function and drug transfer. BJA Educ. 2015, 15, 84-89. [CrossRef]

142. Ha, D.; Yang, N.N.; Nadithe, V. Exosomes as therapeutic drug carriers and delivery vehicles across biological membranes: Current perspectives and future challenges. Acta Pharm. Sin. B 2016, 6, 287-296. [CrossRef]

143. Kinch, M.S.; Yunus, A.S.; Lear, C.; Mao, H.W.; Chen, H.S.; Fesseha, Z.; Luo, G.X.; Nelson, E.A.; Li, L.M.; Huang, Z.H.; et al. FGI-104: A broad-spectrum small molecule inhibitor of viral infection. Am. J. Transl. Res. 2009, 1, 87-98. [CrossRef] [PubMed]

Publisher's Note: MDPI stays neutral with regard to jurisdictional claims in published maps and institutional affiliations.

(C) 2020 by the authors. Licensee MDPI, Basel, Switzerland. This article is an open access article distributed under the terms and conditions of the Creative Commons Attribution (CC BY) license (http://creativecommons.org/licenses/by/4.0/). 